\title{
Let Unions Be Unions: Allowing Grants of BENEFITS DURING REPRESENTATION CAMPAIGNS
}

\author{
Michael J. Hayes $\dagger$
}

\section{INTRODUCTION}

Unions exist to provide assistance to employees; this is their reason for being. ${ }^{1}$ Yet once a union begins a campaign to represent a group of employees, it is legally barred from extending tangible assistance to the workers. The National Labor Relations Board ("NLRB" or the "Board") and courts deem a union grant of benefits to employees during or prior to a representation campaign objectionable conduct that requires setting aside the results of the representation election and holding another election. ${ }^{2}$

In recent years this ban has been particularly controversial with regard to legal assistance by unions. The NLRB, the federal agency that administers the National Labor Relations Act (NLRA), adopted the position that unions could provide "employment-related" legal services during representation campaigns, but two federal circuit courts overruled

$\dagger$ Assistant Professor of Law, University of Baltimore School of Law; B.S. 1985, Cornell University; J.D. 1988, University of Virginia. I am grateful to David Rosenfeld for his valuable insights and provision of sources on this topic. I thank James Coppess and Catherine L. Fisk for their helpful comments on an earlier draft of this article. I commend Kamran Khan, Courtney Swears and Sarah Hornbeck for their excellent research assistance, and thank the University of Baltimore School of Law for providing financial support.

1. This is demonstrated by the preamble of the constitution of the AFL-CIO, by far the largest federation of unions in the United States. The preamble states that the AFL-CIO "is an expression of the hopes and aspirations of the working people of America... We dedicate ourselves to improving the lives of working families, bringing fairness and dignity to the workplace and securing social equity in the Nation." AFL-CIO CONST. pmbl, at http://www.aflcio.org/about/constitution_art00.htm (last visited July 30, 2002).

2. See generally Patrick Hardin, Restrictions on Preelection Activity, 1 THE DEVELOPING LABOR LAW 367 (1992). In two cases, the Board has found that a union's provision of monetary benefits to employees during an organizing campaign was an unfair labor practice under Section 8(b)(1)(A) of the NLRA. See Teamsters Local 952 (Pepsi Cola Bottling Co.), 305 N.L.R.B. 268, 275 (1991); Flatbush Manor Care Ctr., 287 N.L.R.B. 457, 457 (1987). Usually, however, union grants of benefits are challenged as objectionable conduct in an election rather than as unfair labor practices. Id. 
the Board on this issue. ${ }^{3}$ The controversy over unions providing legal assistance to employees has drawn recent attention from scholars, who have proposed modifying ${ }^{4}$ or repealing ${ }^{5}$ the ban on such assistance. This article makes a broader and more provocative proposal: to completely abolish the prohibition on union assistance to employees during a representation campaign.

More specifically, this article advocates allowing unions to provide unconditional benefits, which are benefits offered to employees regardless of whether they manifest support for the union. It is actually impossible for either an employer or union to condition a benefit on how an employee votes, because the National Labor Relations Act ("NLRA") requires that representation elections be conducted by secret ballot. ${ }^{6}$ Unions, however, sometimes offer benefits only to employees who sign a union authorization card or otherwise demonstrate support for the union. These conditional benefits in effect penalize employees who fail to manifest support for the union, and thus interfere with an employee's right to refrain from union support. Such interference is expressly proscribed by Sections 7 and 8(b)(1)(A) of the NLRA.?

By contrast, there is no provision of the NLRA that expressly prohibits unconditional grants of benefits, and this article contends that there is no valid justification for that prohibition. As explained in Part III, the ban on unions providing unconditional benefits during representation campaigns is grounded on a narrow and unrealistic view of the relationship between unions and employees. The purpose of the ban is to ensure that, when employees vote on whether to have union representation, the employees are not distracted by extraneous benefits, but base decisions solely on their assessment of what type of representative the union would provide for their work environment. That purpose conflicts with the reality that providing a workplace representative is just one of many ways that unions assist employees. Allowing unions to provide benefits during representation campaigns would give employees a fuller and more accurate

3. See generally 52d St. Hotel Assocs., 321 N.L.R.B. 624 (1996); Nestle Dairy Systems, 311 N.L.R.B. 987 (1993), enf. denied, 46 F.3d 578 (6th Cir. 1995). But see Freund Baking Co. v. NLRB, 165 F.3d 928 (D.C. Cir. 1999); Nestle Ice Cream Co. v. NLRB, 46 F.3d 578 (6th Cir. 1995).

4. See Michael Carlin, Note, Are Union-Financed Legal Services Provided Prior to a Representation Election an Impermissible Grant of Benefit?: An Analysis of Nestle, Novotel, and Freund, 79 N.C.L. REv. 551 (2001).

5. See Catherine L. Fisk, Union Lawyers and Employment Law, 23 Berkeley J. Emp. \& Lab. L. 57 (2002).

6. See 29 U.S.C. $\S 159(\mathrm{e})(1)(2002)$.

7. Section 7 gives employees "the right to refrain from any or all" activities in support of a union. $I d$. at $\$ 157$. Section $8(\mathrm{~b})(1)(\mathrm{A})$ provides that it is an unfair labor practice for a union "to restrain or coerce employees in the exercise of the rights guaranteed in Section $7 \ldots$... ld. at $\$ 158(\mathrm{~b})(1)(\mathrm{A})$. 
understanding of how a union would impact not only their jobs, but their lives.

This article's proposal to open the door to unconditional union benefits during an organizing campaign will likely be controversial. Part of the controversy stems from the fact that the proposal would reverse a legal rule that has been in place for more than thirty years. A greater source of controversy will be that the proposal would allow unions to do something that employers are forbidden to do. Currently, both unions and employers are prohibited from granting employees unconditional benefits during an organizing campaign. Removing that prohibition just for unions would no doubt spur complaints by employers and their representatives, who would argue that the prohibitions on each side are currently equivalent, ${ }^{8}$ and it would therefore be unfair and unreasonable to remove the limit for just one side.

Such arguments are erroneous. The ban on employer grants and the ban on union grants are actually quite distinct, particularly in their origins and purposes. The main rationale for the ban on employer grants of benefits, as established by the Supreme Court in NLRB v. Exchange Parts, is that such grants are implicitly threatening to employees.' Unions, because they lack the kind of control over the work environment that employers have, are not in a position to use benefit grants to threaten employees. Consequently, very different rationales underlie the ban on a union's grant of benefits. This article takes no position on whether the ban on employer benefits should be repealed, but Part IV explains why it may be reasonable to remove the prohibition for unions while maintaining the prohibition for employers.

Although the proposal to allow union grants of benefits is controversial, it is also feasible. The change in law would not require any action by Congress or even by a court, but could be effectuated by the NLRB. A statutory amendment is unnecessary because, as already noted, there is no provision in the NLRA that expressly restricts unconditional union grants of benefits. The only provision in the statute that even refers to benefits is Section 8(c), the "free speech" provision, which says that an expression of views cannot be used as evidence of an unfair labor practice unless the expression contains a "threat of reprisal" or "a promise of benefit." In the legislative history of the NLRA, there is hardly any discussion of the promise of benefit language, except for brief references to

8. See infra notes $192-95$ and accompanying text (discussing statements by the Board and courts to the effect that the ban on union and employer grants of benefits are equivalent).

9. NLRB v. Exchange Parts, Inc., 375 U.S. 405, 409 (1964).

10. 29 U.S.C. $\S 158(c)(2002)$. 
employer bribery or discrimination. ${ }^{11}$ Therefore, there is no ground for finding that Congress intended the statute to prohibit unions from providing unconditional benefits and assistance during an organizing campaign.

Additionally, the Board's removal of the ban would not breach any Supreme Court precedent. The Court's only decision addressing union grants of benefits, NLRB v. Savair Mfg. Co., ${ }^{12}$ involved conditional benefits that were provided only to employees who signed recognition slips supporting the union. The Court found those conditional benefits constituted objectionable conduct that justified overturning the union's 2220 election victory. ${ }^{13}$ Not only is Savair's holding limited to conditional benefits, but as discussed more fully in Part II, the main rationales for the Court's conclusion logically apply only to benefits conditioned on an employee's demonstration of union support. Thus, with regard to unconditional grants of benefits by unions, the Court's statements in Savair are at best dicta, and do not constrain the Board from revising or repealing its ban.

The Board is also not constrained by circuit court decisions applying the rule against union benefits. As long as the Board sets forth a "reasoned explanation" for its change in policy, the circuit courts should defer to that change. ${ }^{14}$ Congress intended the Board to dominate over the courts in making policy in the labor union arena, and judicial deference to Board policies is required both by the NLRA and the prevailing legal standards on judicial review of administrative agency decisions. ${ }^{15}$

This article proposes a policy change that the Board has full authority to carry out. The Board, in fact, created the prohibition on union grants of benefits ${ }^{16}$ and it should now revisit this policy. The prohibition is harmful to employees and limits their ability to make a fully informed and wellreasoned choice in representation elections.

11. See Charles C. Jackson \& Jeffrey S. Heller, Promises and Grants of Benefits Under the National Labor Relations Act, 131 U. PA. L. REV. 1, 50-51 \& nn.208-13 (1982)(summarizing and citing the legislative history).

12. 414 U.S. 270 (1973).

13. $I d$.

14. See Chelsea Indus. v. NLRB, 285 F.3d 1073, 1076 (D.C. Cir. 2002)(holding that "[ $[$ ] 'reasoned explanation'")(quoting Micro Pacific Dev. Inc. v. NLRB, 178 F.3d 1325, 1336 (D.C. Cir. 1999)).

15. See Michael J. Hayes, After "Hiding the Ball" Is Over: How the NLRB Must Change Its Approach to Decision-Making, 33 RUTGERS L.J. 755, 784-93 (2002).

16. See Wagner Electric Corp., 167 N.L.R.B. 532, 533 (1967); General Cable Corp., 170 N.L.R.B. $1682,1682-83(1968)$. 


\section{Evaluating the Rationales for the Prohibition on UNION GRANTS OF BENEFITS}

\section{A. Introduction}

Union grants of benefits are sometimes referred to by the NLRB and the courts as "bribes"17 or "purchases of votes." purchasing in general elections is a crime under federal law and under the laws of most states ${ }^{19}$ and that bribery is criminal in many contexts, ${ }^{20}$ finding that union benefit grants are bribes to voters would seem to be a sufficient ground to declare them illegal or objectionable in representation elections. However, the term "bribery" is both too narrow and too broad to serve as the basis for barring union grants of benefits. If used in the strict sense of a direct quid pro quo, where the benefit is provided as consideration for an action by the recipient, then bribery does not include unconditional grants of benefits by unions. As noted earlier, representation elections are conducted by secret ballot, therefore a union would be unable to secure an employee's vote in return for a benefit, as contrasted with, for example, a bribe paid to a government official for making a public decision or vote. Moreover, with unconditional benefits, the employee's receipt of the benefit does not depend on how an employee promises or intends to vote.

If bribery is used in its broadest sense, as a benefit offered or provided with the goal of the recipient taking a certain action, then union grants of unconditional benefits would be covered under bribery, but so would many other forms of union and employer conduct that are currently permitted. For example, it is perfectly legal for employers to set their wages and other terms of employment with the goal of discouraging their employees from unionizing. ${ }^{21}$ In addition, both employers and unions are allowed to give employees various types of campaign propaganda, such as buttons and $\mathrm{T}$ shirts, ${ }^{22}$ even though at least one motive for such gifts is to make the

17. See, e.g., Aventura Country Club, 253 N.L.R.B. 416, 416 (1980)(“[A] cash gift or a bribe ... can serve only to corrupt employees in their choice").

18. See, e.g., Nestle Ice Cream Co. v. NLRB, 46 F.3d 578, 584 (6th Cir. 1995)(holding that union's provision of legal services "smacked of a 'purchase' of votes").

19. See Richard L. Hasen, Vote Buying, 88 CAL. L. REV. 1323, 1324 n.1 (2000).

20. See, e.g., 18 U.S.C. $\$ 201$ (2002) (bribery of public officials); MODEL PENAL CODE $\S 240.1$ (1985)(bribery in official and political matters).

21. See Whiteside \& Weinberg, Coping with the Unionization Drive: A Guide for the Careful Employer, 43 THE PRACTICAL LAWYER 45 (1997).

22. See, e.g., NLRB v. Dickinson Press, Inc., 153 F.3d 282, 286-87 (6th Cir. 1998)(finding unions' provision of T-shirts permissible "propaganda"); NLRB v. Coca-Cola Bottling Co. Consol., 132 F.3d 1001, 1005-06 (4th Cir. 1997)(finding union's provision of T-shirts unobjectionable); Okla. Installation Co., 309 N.L.R.B. 776,776 (1992)(finding employer's distribution of caps and T-shirts permissible). 
recipients more likely to vote for the donor. The law also clearly permits unions to promise employees a variety of benefits they will receive if the union wins, even though many bribery statutes equate such offers of benefits with actual grants. ${ }^{23}$

Consequently, labeling unions' grants of benefits as "bribes" is not an adequate basis for prohibiting such grants. The Board and courts must consider that while unions are barred from granting benefits other employer and union actions that also fit the common definition of "bribe" are permitted. The Board and courts should give reasons for the prohibition on union grants of benefits that justify placing such grants on the impermissible side of the line.

\section{B. The Leading Decisions and Their Rationales}

The Board first found union grants of unconditional benefits objectionable in 1967-68, in two cases decided within seven months of each other, Wagner Electric Corp. ${ }^{24}$ and General Cable. ${ }^{25}$ In Wagner Electric, the Board set aside an election won by the Teamsters Union because the union, both before and after the filing of the election petition, ${ }^{26}$ offered employees who "signed up" with the union immediate coverage through life insurance and funeral benefit policies provided by the union. ${ }^{27}$ The Board found that the union's "gift of immediate life insurance coverage is a tangible economic benefit" that "subjects the donees to a constraint to vote for the donor union., ${ }^{28}$ In General Cable, the United Steel Workers gave $\$ 5$ gift certificates to all employees a few days before the election, which the Board deemed objectionable because "the gifts were made as an inducement to support the Petitioner. Such conduct impairs

23. See, e.g., 18 U.S.C. $\S 201$ (1962) (amended 1994) (prohibiting any action that "gives, offers or promises anything of value to any public official") (emphasis added); MODEL PENAL CODE $§ 240.1$ ("person is guilty of bribery ... if he offers, confers or agrees to confer upon another... any pecuniary benefit as consideration for the recipient's decision, [etc.]") (emphasis added).

24. Wagner Electric Corp., 167 N.L.R.B. 532 (1967).

25. General Cable Corp., 170 N.L.R.B. 1682 (1968).

26. See 167 N.L.R.B. at 532 (noting that the union offered benefits on Feb. 2, Feb. 22, and "after it received the Excelsior list" on March 9 and 10).

27. Technically, the Board could have analyzed Wagner Electric as a "conditional benefit" case, because the union conditioned this benefit on an employee's manifesting support for the union (i.e. "signing up"). The Board could have considered how this condition may have pressured employees to forego their Section 7 right to "refrain from" openly supporting a union. See 29 U.S.C. $\S 157$ (1935). The Board, however, did not discuss this condition, or how the condition could have affected employees' exercise of their Section 7 rights to openly support, or refrain from supporting, the union. Instead, the Board analyzed how the grant of the benefit might affect employees' secret ballot voting, a line of reasoning that does not depend on whether the benefit is conditional or unconditional.

28. 167 N.L.R.B. at 533. 
employee free choice.,29

As noted earlier, Board elections are by secret ballots, and so there is no way that a union can know whether an individual voted for or against the union. Hence, an employee's vote cannot affect whether the union provides an employee with a benefit. Therefore, when the Board referred to a "constraint" or "inducement" to vote in favor of the union in Wagner Electric and General Cable, the Board could not and did not mean that the employee would feel motivated to vote yes in order to get or keep the union's benefit. Because the employee gets the benefit regardless of how she votes, the only logical way that the benefit might "induce" the employee to vote yes is if the employee believed he or she owed the union a yes vote in return for the benefit. In subsequent decisions, the Board and courts have confirmed that the rationale of Wagner Electric and General Cable is that union-provided benefits may cause employees to vote yes out of a "sense of obligation" to the union. ${ }^{30}$

The Supreme Court issued its first, and only ruling on the permissibility of union grants of benefits during representation campaigns in 1973, in Savair Manufacturing. ${ }^{31}$ In Savair, the Court found objectionable the union's offer to waive initiation fees for any employees who signed union authorization cards prior to the election. ${ }^{32}$ The Court's holding in Savair applied only to a conditional benefit, where an employee's receipt of the benefit depended on that employee's signing a card. Nonetheless, lower courts and the Board have sometimes relied on dicta in Savair to support their rulings that unconditional grants of benefits by unions are illegal or objectionable. ${ }^{33}$

The Court majority mentioned three rationales for why the union's offer of the benefit justified overturning the union's election victory. First, the Court reasoned that by getting employees to sign authorization cards in return for fee waivers, the union could "paint a false portrait of employee support during its election campaign." ${ }^{34}$ The Court explained that even employees who did not support the union might sign the cards in order to

29. 170 N.L.R.B. at 1682-83.

30. See, e.g., Freund Baking Co. v. NLRB, 165 F.3d 928, 932 (D.C. Cir. 1998) (explaining that union "gifts" like free life insurance "constrain[] employees to vote for the Union out of a sense of obligation"); NLRB v. Coca-Cola Bottling Co. Consol., 132 F.3d 1001, 1005 (4th Cir. 1997); Mailing Serv., Inc., 293 N.L.R.B. 565, 566 n.3 (1989) (arguing that employees who received union-provided benefit "would likely have felt a sense of obligation to the donor, the Union"); Easco Tools, Inc., 248 NLRB 700, 700-01 (1980); Gulf State Canners, Inc., 242 NLRB 1326, 1327 \& nn.11-15 (1979).

31. NLRB v. Savair Mfg. Co., 414 U.S. 270 (1973).

32. Id. at 272-73.

33. See, e.g., Comcast Cablevision v. NLRB, 232 F.3d 490, 495-96 (6th Cir. 2000); Freund Baking Co. v. NLRB, 165 F.3d 928, 932 (D.C. Cir. 1999); Flatbush Manor Care Center, 287 N.L.R.B. 457 (1987); Royal Packaging Corp., 284 N.L.R.B. 317, 318 (1987).

34. Savair, 414 U.S. at 277. 
get the fee waiver, and the union could turn around and use these "false" manifestations of support as a "useful campaign tool,", or even to obtain representative status without an election. ${ }^{36}$ This "false portrait" rationale can logically apply only when union benefits are conditioned, like those in Savair, on employees' outward manifestation of union support before the election. When unions grant benefits without such a condition, employees receive them whether they support the union "falsely," "truly," or not at all, so unions cannot use the benefits to garner false indications of support.

The Court's second rationale was that after employees have signed the cards, though they are not legally or formally bound to vote for the union in the election, "certainly there may be some employees who would feel obliged to carry through on their stated intention to support the union.",37 Lower courts and the Board have sometimes cited this statement in Savair as endorsing the position taken in Wagner Electric and General Cable that union grants of benefits improperly motivate employees to vote for the union out of a "sense of obligation" to repay the union. However, the Court in Savair does not say that the employees' feeling of obligation would be to repay the union, but rather that the employees "would feel obliged to carry through on their stated intention" expressed in signing the cards. $^{38}$ Consequently, like the false portrait rationale, this rationale of sense of obligation to "carry through" would also apply only when employees are asked to openly demonstrate union support, and would not exist when a union proffers benefits without demanding such a demonstration.

The final rationale the Court majority mentioned was that " $[t]$ he failure to sign a recognition slip may well seem ominous to nonunionists who fear that if they do not sign they will face a wrathful union regime, should the union win." ${ }^{39}$ Strictly speaking, this rationale could also be said to apply only when a union asks employees to "sign" something. Unlike the other two rationales, though, it could also logically apply to cases of unconditional benefits, because employees could feel similarly threatened if they rejected a union benefit. Indeed, this rationale logically applies to any employee act, or failure to act, that could be interpreted as indicating lack of support for the union. Consequently, this rationale "proves too

35. Id.

36. Id. at $279-280$.

37. Id. at 277-78.

38. Later in the Savair decision, in footnote 6, the Court majority cited Wagner Electric and General Cable and parenthetically referred to their "constraint" and "inducement" rationale. The Court, however, did not discuss this rationale at all, and simply cited these cases in support of the statement that "[t]he NLRB itself has recognized in other contexts that promising or conferring benefits may unduly influence representation elections." See 414 U.S. at 279 n.6.

39. Savair, 414 U.S. at 281 . 
much" as a basis for prohibiting union conduct, and probably for this reason has not subsequently been relied on in cases barring union grants of benefits.

A couple of years after Savair, the United States Court of Appeals for the Sixth Circuit suggested another rationale for restricting union grants of benefits that has been followed in subsequent cases. In Basic Wire Products ${ }^{40}$ the Sixth Circuit held that union grants of benefits during election campaigns were objectionable because "they tend to influence votes without relation to the merits of the election." Seven years later, in $L \& J$ Equipment, ${ }^{42}$ the United States Court of Appeals for the Third Circuit declared that this "irrelevant to the merits" rationale was the foundation for the rule against unions providing benefits during election campaigns. The Third Circuit asserted that the prohibition is "rooted in the idea that an employee's vote should be governed only by consideration of the advantages and disadvantages of unionization in his or her work environment, and not by any extraneous inducements of pecuniary value." ${ }^{, 43}$ In a number of subsequent decisions, courts of appeals and the Board have identified the "irrelevant to the merits" rationale as a main reason for curbing union-provided benefits during election campaigns. ${ }^{44}$

The Sixth Circuit has even established irrelevance to the election's merits as a requirement for banning a union benefit, explaining in Comcast Cablevision-Taylor that the benefit's lack of relation to the election was the second part of the "test" for determining whether the benefit justified setting aside the election. ${ }^{45}$ The Sixth Circuit even linked the "irrelevance to merits" requirement to the "sense of obligation" rationale discussed previously, indicating that "a benefit impos[ing] a sense of obligation" fails the "merits" test, ${ }^{46}$ apparently reasoning that the employees' feelings of obligation have no relation to the true issues in the election.

Closely related to the "irrelevant to the merits" rationale is a ground the Sixth Circuit offered in Nestle Ice Cream, ${ }^{47}$ that it's improper for employees to vote with the motive of continuing to receive benefits from the union after the election. The Sixth Circuit held in Nestle that the

40. NLRB v. Basic Wire Prods., Inc., 516 F.2d 261 (6th Cir. 1975).

41. Id. at 265 .

42. NLRB v. L \& J Equip. Co., 745 F.2d 224, 231(3rd Cir. 1984).

43. Id. at 231 .

44. See, e.g., Comcast Cablevision v. NLRB, 232 F.3d 490, 495 (6th Cir. 2000); Freund Baking Co. v. NLRB, 165 F.3d 928, 933 (D.C. Cir. 1999); Nestle Ice Cream Co. v. NLRB, 46 F.3d 578, 583 (6th Cir. 1995); 52nd St. Hotel Assocs., 321 N.L.R.B. 624, 635 (1996).

45. See Comcast, 232 F.3d at 495-96. The court said that the first part of the test is that the benefit must be sufficiently desirable to the offeree "to have the potential to influence that person's vote." Id. at 495 .

46. Id. at 495.

47. Nestle Ice Cream Co., 46 F.3d at 578. 
union's provision of legal services created "the danger" that the benefit would cause "the employees to feel obliged to vote for the Union simply out of a desire to continue receiving the benefit." on to explain that "the employees might vote for the Unions because the employees hoped that the attorney would continue to pursue that particular suit, rather than because the Union's overall representation of the employees - at the negotiating table with the employer, with insurance companies, with legislators, and so forth - merited election., ${ }^{, 49}$

The last of the rationales commonly advanced by the Board and courts to find union provision of benefits objectionable is that union-supplied benefits disrupt the "laboratory conditions" sought for an election and therefore impair the employees' free choice. ${ }^{50}$ Professors Derek Bok and Catherine L. Fisk have described this rationale as the Board's condemning "crass" or "unseemly" exchanges of union benefits for votes or support. When relying on this rationale, the Board and the courts typically resort to conclusory or moralistic language, such as: "[when] gifts of substantial value were offered by the Union as part of its campaign, we find that laboratory conditions did not exist" ${ }^{, 52}$ or "outright gifts by a union to prospective members... have no purpose other than to pervert the employee's free choice." 53 In a few cases, the Board has more specifically described how the union benefit impairs employees' free choice, and in these cases the Board has invoked one of the other rationales previously discussed. For example, the Board indicated in Mailing Services that the impairment was due to the "sense of obligation" rationale, ${ }^{54}$ while in Drilco, the Board used reasoning similar to the "irrelevant to the merits" rationale in holding that a benefit was impermissible because its value was "so great as to divert the attention of employees away from the election and its purpose." ${ }^{.55}$

48. Id. at 584 .

49. Id. at 585. Professor Catherine L. Fisk has pointed out that with regard to the specific benefit at issue in Nestle, union lawyers pursuing a lawsuit on behalf of employees, the concern that the benefit will "continue" only if the union wins the election is misplaced, because the lawyers would be ethically obligated to maintain the lawsuit on behalf of their employee-clients. See Fisk, supra note 4, at 91.

50. See, e.g., NLRB v. River City Elevator Co., 289 F.3d 1029, 1031 (7th Cir. 2002).

51. See Derek C. Bok, The Regulation of Campaign Tactics in Representation Elections under the National Labor Relations Act, 78 HARV. L. REV. 38, 56-57 (1964); Fisk, supra note 4 , at 69 .

52. NLRB v. River City Elevator Co., 289 F.3d 1029, 1033 (7th Cir. 2002).

53. NLRB v. Whitney Museum of Am. Art, 636 F.2d 19, 22 (2nd Cir. 1980).

54. Mailing Servs., Inc., 293 N.L.R.B. 565, 565-66 \& n.3 (1989).

55. Drilco v. Int'l Ass'n of Machinists \& Aerospace Workers, 242 N.L.R.B. 20,21 (1979). 


\section{Criticisms of Rationales}

Both judges and scholars have criticized the prohibition on unions granting benefits during election campaigns. Usually, though not always, the critics have questioned the ban on benefit grants by unions and employers.

In a frequently cited 1982 law review article ${ }^{56}$ labor lawyers Charles C. Jackson and Jeffrey S. Heller contended that "the National Labor Relations Act ... does not prohibit non-compulsive pre-election efforts by employers and unions to persuade employees even if those efforts consist of promises and grants of benefits. ${ }^{, 57}$ Jackson and Heller were specifically critical of the rationale that benefit grants might cause employees to vote with "improper" motivations, such as a sense of obligation or a desire to continue to receive the benefits. They observed that "[i]n any given case, no one - including the Board and the courts - knows what motivates the employee vote." 58 Similarly, they pointed out that no one knows how employees might react to union benefit grants, positing for example that "if the benefits are conferred only for a short period of time, then the message conveyed may be that the union is only interested in increasing membership rolls." 59

In questioning the Board's suppositions about employee motivation, Jackson and Heller relied on the empirical research of Professors Getman, Goldberg, and Herman. ${ }^{60}$ In this famous and controversial ${ }^{61}$ study, Professor Getman and his colleagues examined whether empirical data

56. See Jackson \& Heller, supra note 10. For examples of references to this article by scholars, see Fisk, supra note 4, at 61 n.17; Mark Barenberg, Democracy and Domination in the Law of Workplace Cooperation: From Bureaucratic to Flexible Production, 94 Colum. L. Rev. 753, 783 n.82 (1994); John W. Teeter, Jr., Keeping the Faith: The Problem of Apparent Bias in Labor Representation Elections, 58 U. CIN. L. REv. 909, 961 n.208 (1990)(describing the article as a "provocative critique"); Rebecca Hanner White, Modern Discrimination Theory and the National Labor Relations Act, 39 WM. \& MARY L. REV. 99, 108 n.49 (1997).

57. Jackson \& Heller, supra note 10 , at 66 .

58. Id. at 55 .

59. Id. at 54-55.

60. See generally Julius GeTMAN ET AL, UniOn REPRESENTATION ELECTIONS: LAW AND REALITY (1976). Jackson and Heller initially cited this study at 131 U. PA. L. Rev. at 4 n.13, and discussed it more fully at 131 U. PA. L. REV. at 54-58.

61. Several scholars wrote an article criticizing the study's methodology, while Professors Getman, Goldberg and others responded with articles defending the study. See COX ET al, Labor LaW 186-91 (13th ed. 2001); Michael C. HaRPER \& Samuel ESTREICHER, LABOR LAW 355-58 (4th ed. 1996) (summarizing the articles debating Getman, Goldberg, and Herman's methodology). In Jackson and Heller's article, they acknowledged the dispute over the study's methodology, but stressed that "no critic has compiled a study that disproves the contentions of [Getman, et. al.] and supports traditional NLRB campaign regulation." 131 U. PA. L. REv. at 57-58 (emphasis in original). 
supported the factual assumptions that undergird many of the Board's regulations of conduct during election campaigns, including the rule against grants of benefits. With regard to employers' grants of benefits, the study found that "[s]uch grants, though commonplace in the elections studied, had no demonstrable effect on vote."62 In fact, the study showed that employees who received promises and grants of benefits from their employers "were actually more likely to vote for union representation than were other employees." ${ }^{63}$ That finding at least puts in doubt the Board's view that a grant of benefits by an election party will motivate employees to vote for that party.

The Court of Appeals for the District of Columbia Circuit relied on the Getman study in 1996, in Skyline Distributors,${ }^{64}$ to question the ban on grants of benefits during election campaigns. In an opinion by Chief Judge and former labor law professor Harry Edwards, ${ }^{65}$ and joined by Circuit judges Henderson and Tatel, the D.C Circuit observed that "the premise" of the ban "has been challenged by preeminent labor law scholars, who question whether certain ULPs [unfair labor practices] do in fact adversely affect free and uncoerced choice by workers. ${ }^{, 66}$ The court then quoted a paragraph from the Getman study that explained that the evidence did not support the Board's and court's assumptions about how employer promises and grants of benefits affect employees. ${ }^{67}$ The D.C. Circuit recognized it did not have the authority to overturn the ban on benefit grants, ${ }^{68}$ and so Skyline Distributors cannot be relied on as precedent for removing that ban. Nonetheless, the D.C. Circuit's criticisms of the ban are significant because they were extensive, carefully thought out, and were probably more than dicta because they were an important part of the court's reasoning for its conclusion that benefit grants are insufficient grounds for a bargaining order. $^{69}$ Two years after Skyline Distributors, yet another D.C. Circuit judge, A. Raymond Randolph, cited the Bok and Gorman article as "severe criticism" of the rule against grants of benefits during election campaigns. ${ }^{70}$

Professor Getman and others have questioned the accuracy of the

62. GETMAN, supra note 58 , at 151.

63. Id.

64. Skyline Distribs. v. NLRB, 99 F.3d 403 (D.C. Cir. 1996).

65. See 2 almanac of the Federal Judiciary, D.C. Cir. Section at 5 (Christine Housen, et. al. eds. 2002).

66. 99 F.3d at 409.

67. Id.

68. Id.

69. The court's statements challenging the validity of the ban were the bases for its finding that benefits grants are not a "grave violation," which in turn supported the D.C. Circuit's holding that the Board had erred in ruling that the benefit grants justified the remedy of a bargaining order. See 99 F.3d at 410-12.

70. See Perdue Farms, Inc. v. NLRB, 144 F.3d 830, 839 (D.C. Cir. 1998) (Randolph, J., dissenting). 
Board's supposition that grants of benefits motivate employees to vote out of a sense of obligation or fear. Professor Catherine Fisk has challenged the Board's view that such motivations (assuming they exist) are somehow improper. In her description of the Board's "sense of obligation" rationale, Professor Fisk observed that "[o]f course, all union elections are affected in part by the employees' perception of what is going to be in their economic best interest - will unionization lead to higher wages and better working conditions or not?"' Later in the article, Professor Fisk renounced the sense of obligation rationale, asserting that:

[T]o the extent employees feel gratitude to the union for enforcing their statutory rights, that is precisely the sort of sentiment that legitimately should influence votes in union elections. Constituents re-elect their legislators in part because of what they have done for them. It would be impermissible for legislators to buy votes for cash, but certainly it is not wrong for the legislators to offer assistance with government agencies or other forms of constituent service (as long as the legislator of course does not abuse her power in doing so). ${ }^{72}$

In maintaining that employee gratitude and self-interest are "legitimate" influences in employees' voting, Professor Fisk also implicitly challenged the rationale that benefit grants cause employees to vote based on "extraneous" factors that are "irrelevant" to the "merits" of the election. ${ }^{73}$ That rationale will be examined and criticized more fully in Part III.

As critics like Professor Fisk, Professor Getman, and others discussed in this section have demonstrated, most of the rationales that have been advanced for barring union benefit grants are based on inaccurate or questionable assumptions about what employee-voter motivations are or should be. The only significant rationale not yet discussed is that the ban is necessary to protect the "laboratory conditions" desired for elections. The Board and courts, however, have repeatedly acknowledged that laboratory conditions are an "ideal" that is often impossible to achieve in the real world. ${ }^{74}$ Indeed, the Board in Liberal Market, Inc., within only a few years

71. Fisk, supra note 4 , at 68 .

72. Id. at $90-91$.

73. See supra notes $39-45$ and accompanying text (discussing the "irrelevant to the merits" rationale).

74. See, e.g., Avondale Indus. v. NLRB, 180 F.3d 633, 636 (5th Cir. 1999)(“'[w]hile 'laboratory conditions' represent the ideal, 'clinical asepsis is an unattainable goal in the real world of union organizational efforts"') (quoting NLRB v. Sumter Plywood Corp., 535 F.2d 917, 920 (5th Cir. 1976)); Amalgamated Servs. v. NLRB, 815 F.2d 225, 227 (2nd Cir. 1987) ("the idea of laboratory conditions must be realistically applied"); NLRB v. Herbert Halperin Distrib. Corp., 826 F.2d 287, 290 (4th Cir. 1987) ("[w]hile the Board strives to maintain 'laboratory conditions' $\ldots$ in reality these conditions are often 'less-than- 
after establishment of the "laboratory conditions" standard, conceded that "the Board must recognize that Board elections do not occur in a laboratory where controlled or artificial conditions may be established." Market, the Board described an approach that it has followed many times since, explaining:

We seek to establish ideal conditions insofar as possible, but we appraise the actual facts in the light of realistic standards of human conduct. It follows that elections must be appraised realistically and practically, and should not be judged against theoretically ideal, but nevertheless artificial, standards. In this connection, we note that a realistic appraisal of the effect of antecedent conduct upon a Board election must, of course, be concerned with particular acts and their effect upon those of the voters who are directly involved; it must also be concerned, however, with the overall picture of how the totality of the conduct affects not only the voters directly involved, but any others who may or may not be indirectly affected because they are within the voting unit. In some cases, a nice balancing of these considerations may be required. ${ }^{76}$

Scholars have also observed that the Board's actual regulation of representation elections is not nearly as strict as the "laboratory conditions" standard would lead one to believe. ${ }^{77}$

Perhaps the most significant example of the gap between the Board's aspirational laboratory conditions standard and its actual regulation of election conduct is the Board's policy that it will not regard employer or

perfect"); Shipowners Assn. of the Pac. Coast, 110 N.L.R.B. 479, 480 (1954) ("[t]he Board recognizes that realistically elections do not occur under controlled laboratory conditions and that circumstances surrounding working conditions in various industries require an adaptation of established standards to those conditions").

75. Liberal Mkt. Inc., 108 N.L.R.B. 1481, 1482 (1954). Liberal Market was decided only six years after the Board first set out the "laboratory conditions" standard in General Shoe Corp., 77 N.L.R.B. 124 (1948).

76. Id. at 1482. For examples of Board decisions relying on Liberal Market and following its approach, see, Midland Nat'l Life Ins. Co., 263 N.L.R.B. 127, 130 (1982); Newport News Shipbldg. \& Dry Dock Co., 239 N.L.R.B. 82, 90 \& 91 n.28 (1978); Am. Enka Co., 231 N.L.R.B. 1335, 1343 (1977); Owens-Corning Fiberglas Corp., 179 N.L.R.B. 219,223 (1969).

77. See, e.g., Bok, supra note 49 , at $39-41$ (discussing variations in how strictly the Board has applied the "laboratory conditions" standard); Katherine Van Wezel Stone, Labor and the Corporate Structure: Changing Conceptions and Emerging Possibilities, $55 \mathrm{U}$. CHI. L. REv. 73, 166 n.377 (1988) ("the NLRB has weakened its approach to regulation of election conduct, and has softened its approach to the problem of coercion."); James W. Wimberly, Jr. \& Martin H. Steckel, NLRB Campaign Laboratory Conditions Doctrine and Free Speech Revisited, 32 MERCER L. REV. 535 (1981) (discussing the history of the application of the laboratory conditions standard). 
union misrepresentations as objectionable conduct. ${ }^{78}$ Under this policy, the Board has allowed false pre-election statements that could logically be expected to have a major influence on voters, such as a union's statement that " $t$ t]he National Labor Relations Board of the Unite States of America wants the workers [of the Respondent company] to have a union,"79 an employer's false assertion that the union would charge every new member an initiation fee, ${ }^{80}$ and an employer's untrue statements that the union's officials had caused violent, disastrous strikes at other companies. ${ }^{81}$ Thus, in cases of misrepresentation and in other contexts, the Board and courts have been less than rigorous in requiring that parties truly conform to the idealized "laboratory conditions" standard. Consequently, in terms of justifying the Board's prohibition on union grants of benefits, the Board's bare invocation of the laboratory conditions standard is quite unconvincing. At the very least, it is incumbent on the Board to explain why union grants of benefits are more destructive of employee freedom of choice than misrepresentations and other election conduct the Board allows, and this the Board has never done.

In addition to the conceptual problems with the rationales that have been advanced to support the prohibition on union grants of benefits, a very serious practical problem is that the prohibition is applied inconsistently and unpredictably. Professor Catherine Fisk has cogently summarized some of the inexplicable distinctions between what has been allowed and what has not. Regarding union benefits, she observed that "giving away union jackets costing $\$ 16$ each, or $\$ 5$ gift certificate is not permissible, but giving away T-shirts is. Hosting a modest party on or about election day is permissible; hosting a lavish party is not." ${ }^{, 82}$ With regard to employer benefits, Professor Fisk noted that, for no clear reason, employers can provide transportation to enable employees to vote, but cannot provide child care for the same purpose. ${ }^{83}$ These sorts of mystifying distinctions between the permissible and impermissible lead Professor Fisk to conclude that "the whole body of law about pre-election benefits is, at best, fraught with difficulty and, at worse, an incoherent trap for the unwary." ${ }^{, 4}$

For unions, there are "incoherent" and irrational precedents governing some of the most common union practices in representation elections. One crucial issue is unconditional waivers of fees and dues, which unions regularly provide in election campaigns. The Board and courts permit such

78. See Midland Nat'l Life Ins. Co., 263 N.L.R.B. 127 (1982) (the case establishing the policy); Hardin, supra note 2, at 350-52 (discussing cases applying the policy).

79. TEG/LVI Envtl. Servs., Inc., 326 N.L.R.B. 1469, 1469 \& n.2 (1998).

80. Allied Stores Corp., 308 N.L.R.B. 184, 200 (1992).

81. Midland Nat'l Life Ins. Co., 263 N.L.R.B. at 128.

82. Fisk, supra note 4 , at $71-72 \&$ nn.71-72.

83. Id. at $72-73$.

84. Id. at 73 . 
waivers in certification elections, where the issue is whether the union will become the employees representative. ${ }^{85}$ However, in decertification elections, where the issue is whether the union will continue to represent employees, the Board has barred waiver of back dues.

The Board's rule allowing unconditional waiver of fees and dues in certification elections was endorsed by the Supreme Court in Savair ${ }^{86}$ The Court reasoned that such waivers were permissible during an election campaign because "'employees otherwise sympathetic to the union might well [be] reluctant to pay out money before the union ha[s] done anything for them" and waiver of fees and dues "would remove this artificial obstacle to their endorsement of the union." "87 In many subsequent cases, the Board and courts have relied on this "removal of artificial obstacle" principle, to allow unions to waive fees and dues for employees in certification election campaigns. ${ }^{88}$

By contrast, the Board established a ban on such waivers in decertification elections in Loubella Extendables. ${ }^{89}$ In Loubella, the union won a decertification election petitioned for by the employer, but the Board majority overturned the union's victory because the union informed new employees, who had not yet paid union fees or dues, that the union would not seek to collect those delinquencies, should the union win the upcoming election. $^{90}$ The Board majority reasoned that the union's "forgiveness" of the delinquencies "constitutes a grant of financial benefit which is indistinguishable from other grants of immediate benefit which we have found to be objectionable union conduct." 91 The Board reaffirmed the ban in McCarty Processors, ${ }^{92}$ where the Board overturned the union's win in a decertification election because during the campaign, after the employer stopped "checking off" dues, ${ }^{93}$ the union informed employees that it would

85. See Jackson \& Heller, supra note 10 , at 22 \& n. 99.

86. NLRB v. Savair Mfg. Co., 414 U.S. 270 (1973).

87. Id. at 272 n.4. (quoting Amalgamated Clothing Workers v. NLRB, 345 F.2d 264, 268 (2d Cir. 1969)).

88. See, e.g., NLRB v. River City Elevator Co., 289 F.3d 1029, 1032 (7th Cir. 2002); Associated Ready Mixed Concrete v. NLRB, 108 F.3d 1182, 1184 (9th Cir. 1997); NLRB v. Whitney Museum of Am. Art, 636 F.2d 19, 21 (2d Cir. 1980); NLRB v. Con-Pac, Inc., 509 F.2d 270, 272 (5th Cir. 1975); Ida Lace, Inc., 275 N.L.R.B. 211, 211 \& n.6 (1985); Plastic Composites Corp., 210 N.L.R.B. 728,728 (1974).

89. Loubella Extendables, Inc., 206 NLRB 183, 184 (1973).

90. Id. at $183-84 \&$ n.9. There was also no evidence that the union ever indicated to employees that it would try to collect on the delinquencies if it lost the election and thus was no longer the collective bargaining representative of the employees. To the contrary, after the evidentiary hearing, "the Regional Director noted a lack of evidence that the Union collected from employees it no longer represented." Id. at 184 (Fanning, Member, dissenting).

91. Id. at 183 .

92. 286 N.L.R.B. 703,703 (1987).

93. "Check-off system" refers to a "procedure by which an employer deducts union 
not seek to collect back dues for the period after checkoff ceased. ${ }^{94}$ The Board found that the union's "waiver of accrued back dues ... constituted the granting of a financial benefit analogous to" such objectionable benefits as jackets or gift certificates. ${ }^{95}$

In cases prohibiting union waiver of back dues in decertification elections, the Board has completely disregarded the Supreme Courtendorsed principle that it is legitimate for unions to "remove artificial obstacles" to employee support, which the Board has repeatedly invoked when allowing union dues waivers in certification elections. ${ }^{96}$ The Board's departure from this accepted principle in decertification elections is unjustified because back dues are just as much an "artificial obstacle" for an incumbent union in a decertification election, as dues and initiation fees are for a prospective union in a certification election.

In certification elections, when unions waive dues, they commonly explain that the waiver will be in effect until the negotiation of a contract. ${ }^{97}$ That is because unions recognize, as the Supreme Court did in Savair, ${ }^{98}$ that employees are "reluctant" to be obliged to pay dues in the period before the union has done something for them, namely, negotiated better employment terms and conditions. This creates a concern for the union, a concern that Savair called "legitimate," union representation may vote "no" in order to avoid paying dues before they have a contract.

Unions in decertification elections have the same concern. As a result of the Board's "contract bar" doctrine, ${ }^{100}$ decertification elections usually occur when there is not a collective bargaining agreement in effect. ${ }^{101}$ At

dues directly from the employees wages and remits those dues to the union." BLACK'S LAW DiCTIONARY 231 (7th ed. 1999).

94. McCarty Processors, 286 N.L.R.B. at 703.

95. Id. at 703 (citing Owens-Illinois, 271 N.L.R.B. 1235, 1235 (1984) and Gen. Cable Corp., 170 N.L.R.B. 1682, $1682(1968)$ ).

96. See supra notes $84-87$ and accompanying text.

97. See, e.g., Farrell v. Int'l Bhd. of Teamsters, 888 F.2d 459, 460 (6th Cir. 1989); NLRB v. L.D. McFarland Co., 572 F.2d 256, 259 (9th Cir. 1978); NLRB v. Con-Pac, Inc., 509 F.2d 270, 272-73 (5th Cir. 1975); NLRB v. Wabash Transformer Corp., 509 F.2d 647, 649-50 (8th Cir. 1975); Bakery, Confectionery \& Tobacco Workers Int'l Union, Local 213, 261 N.L.R.B. 773, 782 (1982); Polyflex M Co., 258 NLRB 806, 807 (1981); Tri-State Mech., Inc., 1995 N.L.R.B. LEXIS 1028, at p.*159 (A.L.J. William J. Pannier III, Oct. 18, 1995); Aero Indus., Inc., 1992 N.L.R.B. LEXIS 1107, at p.*76 (A.L.J. Howard Edelman, Sept. 21, 1992).

98. Savair, 414 U.S. at $272-74$ n. 4 .

99. Id.

100. Under the contract bar doctrine, a "current and valid contract will ordinarily prevent the holding of an election." Hardin, supra note 2, at 523 (1992).

101. See Douglas Ray, Industrial Stability and Decertification Elections: Need for Reform, 1984 Ariz. St. L.J. 257, 263-68 (discussing times when decertification elections can occur). 
that time, a union has reason to worry that employees will believe the union is "doing nothing" for them. For example, the union in McCarty Processors informed employees it was waiving dues for months when employees have been without a contract. $^{102}$ In a decertification election, dues give employees an even greater incentive to vote "no" because a union victory could result not only in employees paying dues after the election, but also being held liable for dues that accrued preceding the election. ${ }^{103}$ Therefore, unions in decertification elections share the "legitimate" interest in removing dues as an "artificial obstacle" to employee support, but the Board forbids this practice. ${ }^{104}$

Even more important than the Board's inconsistent positions on dues waivers is the tendency to mischaracterize union promises of benefits as actual grants of benefits. This is a serious error because the law on union promises of benefits is supposed to be more permissive than union grants of benefits. Indeed, the general rule is that unions are totally free to make promises to employees about the benefits they will receive, if the union is elected as their representative. ${ }^{105}$ The Board and courts invalidly restrict that freedom when they view a union's promise of benefit as an actual benefit grant.

Recently, in Comcast Cablevision-Taylor,${ }^{106}$ the Sixth Circuit voided a union's election victory because the union announced prior to the election that it would pay the transportation and hotel expenses of employees to attend a cable industry meeting in Chicago. ${ }^{107}$ The court applied the "grant of benefits" analysis to the Chicago trip, comparing it to cases where unions provided hats, T-shirts or jackets. ${ }^{108}$ However, unlike the employees in those cases, the employees in Comcast Cablevision did not receive the benefits before they voted, because the trip and meeting occurred "the

102. McCarty Processors, 286 N.L.R.B. at 704.

103. Member Fanning recognized this in his dissent in Loubella Extendables, stating that " $[t]$ he appeal of forgiveness of accrued dues, 'if the Union wins,' is a mixed appeal which does not necessarily constitute a grant of financial benefit... To an employee mainly seeking relief from back dues, a 'No' vote is apt to achieve that result without future obligations much more appealingly than a 'Yes' vote with the assumption of dues obligations for an indeterminate time in the future if the Union wins." 206 N.L.R.B. at 184 (Fanning, dissenting).

104. The Board's rules on grants of dues waivers are rendered all the more unintelligible by the Board's creation of an exception allowing unions to waive back dues during election campaigns for employees whose dues liability accrued while working for a different employer than the one involved in the election. See, e.g., Associated Ready Mixed Concrete, Inc., 108 F.3d 1182, 1185 (9th Cir. 1997); Andal Shoe, 197 N.L.R.B. 1183 (1972).

105. Carlin, supra note 3, at $554 \&$ n. 17 (2001).

106. Comcast Cablevision v. NLRB, 232 F.3d 490, 490 (6th Cir. 2000)

107. Id. at $492-93$.

108. Id. at 496 (citing NLRB v. Shrader's, Inc., 928 F.2d 194, 194 (6th Cir. 1991) and Owens-Illinois, Inc., 271 N.L.R.B. 1235, 1235 (1984)). 
weekend following the election." ${ }^{\prime 199}$ Interestingly, in the course of the Sixth Circuit's opinion, the court referred approvingly to the Board's ruling in Mailing Services that "[a]lthough the union was free to promise employees that they would receive this benefit... the union was precluded from providing [the benefit] to them shortly before the election." "10 The Sixth Circuit completely overlooked this significant distinction between "promise" and "provision" when it determined the union's announcement of a trip was an objectionable benefit." ${ }^{111}$ Comcast Cablevision demonstrates that the Board is not immune from mistaking promises of benefits for grants of benefits, since the Board concluded that the union provided a permissible benefit. ${ }^{112}$

In sum, the underlying rationales for the prohibition on union grants of benefits are all conceptually flawed, and the prohibition itself is applied erratically. The case for retaining the prohibition is therefore, extremely weak.

\section{THE CORE ISSUE: "RELEVANT CONSIDERATIONS" FOR VOTERS}

\section{A. How the Board and Courts Draw the Line: Defining a "Sphere of Relevance"}

As noted earlier, ${ }^{113}$ the Board's and courts' prohibition of union grants of benefits contrasts with their acquiescence to other forms of employer and union conduct that have the same objective of persuading employees to vote a certain way. To justify the conclusion that union grants of benefits are an objectionable form of persuasion, the Board and courts have typically offered one or more of the rationales discussed in Part II. ${ }^{114}$ These

109. Id. at 493.

110. Id. at 497-98 (quoting Mailing Servs., Inc., 293 N.L.R.B. 565, 565-66 (1989)) (emphasis added).

111. Arguably, the Sixth Circuit could have found the promise of the trip objectionable, based on a line of cases that deem objectionable union promises of benefits that are not ordinarily provided to union members and that are contingent on the union winning the election. See, e.g., Trencor, Inc. v. NLRB, 110 F.3d 268, 268 (5 $5^{\text {th }}$ Cir. 1997)(union's promise to hold "biggest party in the history of Texas" if the union won); Crestwood Manor, 234 N.L.R.B. 1097, 1097 (1978)(discussing union's promise to hold a raffle for a $\$ 100$ prize if union won). The Sixth Circuit, however, did not rely on these or any other "promise of benefit" cases, and erroneously analyzed the union's announcement of the trip solely as a grant of benefit.

112. Comcast Cablevision, 232 F.3d at 494- 495 (Regional Director and Board found that trip was too insubstantial to affect employees' votes).

113. See infra Part II.A.

114. See supra notes 23-54 and accompanying text. Research by Professor Catherine L. Fisk also demonstrates that these have been the virtually exclusive rationales given for 
justifications for the prohibition against union grants of benefits reflect a concern that the union's provision of a benefit may instill either a sense of obligation in an employee or a desire to continue receiving the benefit. The possibility that one of those motives might impact employee voting violates the "laboratory conditions" standard for elections because those motives are irrelevant to the merits of a representation election.

The Board and courts have drawn the line between permissible and impermissible forms of persuasion by defining properly relevant considerations for representation elections. Campaign conduct that stimulates voter considerations outside this "sphere of relevance," such as union grants of benefits, can appropriately be proscribed. Of course, once the Board and courts undertook to define this sphere, they had to set its boundaries. In union grants of benefits cases, both the Board and courts have limited the sphere of relevance "spatially" - to what the union could do for employees in their work environment. The courts and, less frequently, the Board have also limited the sphere "temporally" - to what the union could do after the election should it win.

The Board in 52nd St. Hotel Assocs. declared that "[t]he common thread running through all these cases [of union benefit grants]" was the following precept stated by the Third Circuit in $L \& J$ Equipment: "an employee's vote should be governed only by consideration of the advantages and disadvantages of unionization in his or her work environment, and not by any extraneous inducements of pecuniary value." 115 The Board next stated that the union's suit for overtime pay "did not offend this policy because the legal services it provided were integral to the workers' employment-related concerns," and therefore the lawsuit was distinguishable from benefits like medical testing and life insurance that are "extraneous to efforts to vindicate employment-related concerns ...."116 The employees' workplace is the "spatial" limit of relevance; any union

prohibiting unions' unconditional grants of benefits during election campaigns. Professor Fisk identified "[f]our dominant concerns" that the Board and courts have relied on to justify barring grants of benefits by employers or unions. Two of those concerns - that benefits can be used as an implied threat or to "create a false picture of substantial support" - do not logically apply to union grants of unconditional benefits. The other two concerns that benefits may motivate an employee's vote and that "crass economic inducements" are "unseeml[y]" - overlap with the rationales discussed in this section. See Fisk, supra note 4, at $68-70$.

115. 52nd St. Hotel Assocs., 321 N.L.R.B. 624, 635 (1996) (emphasis added) (quoting NLRB v. L \& J Equipment Co., 745 F.2d 224, 231 (3d Cir. 1984)).

116. Id. at 635 . Here, the Board stated, "Of course, this would be a very different case if it had been established that the [union] granted employees legal services for matters unrelated to their efforts to improve their terms and conditions of employment, such as a divorce proceeding or a personal injury lawsuit." Id. at 635 n.57. The Board then cited $N L R B$ v. Madisonville Concrete Co., 552 F.2d 168 (6th Cir. 1977) (finding objectionable the union's provision of legal services to an employee for a traffic ticket). 
efforts to assist employees other than improving conditions in their work environment are "extraneous".

With regard to the "temporal" limit preventing unions from assisting employees until after the election, the Board's decisions have been mixed. It should be noted that the Board in 52nd St. Hotel Assocs. held that a union was permitted to assist employees with a lawsuit before the election as long as the suit involved "employment-related concerns". 117 The Board made similar rulings in three other cases in the $1990 \mathrm{~s}^{118}$, but for a number of reasons, the Board's rulings in these cases can only serve as authoritative precedent for lawsuits. ${ }^{119}$ The Board rendered a more generally applicable ruling in 1991 in NTA Graphics, ${ }^{120}$ rejecting the employer's argument that the union had engaged in objectionable conduct by paying "sacrifice benefits" before the election to employee-voters who had allegedly been unlawfully discharged. ${ }^{121}$ The Board based its conclusion that the sacrifice benefits were unobjectionable on its findings that "sacrifice benefits have been provided for in the International Union's constitution" and "were a normal incident of union membership." ${ }^{122}$ The Board distinguished this holding from its 1989 decision in Mailing Services in which "benefits apparently were made available to employees regardless of whether they were union members." 123 The Board then explained: "Nothing in Mailing Services should be interpreted as indicating that a union will be found to have interfered with an election merely by providing to its new members, even during the critical period, benefits to which they would normally be entitled by virtue of their union membership." 124 Under the rationale of NTA Graphics, unions could provide employee-voters with any benefits that the union normally offers to its members, as long as the union could show they were new members. The Board, however, has never again followed NTA Graphics in a union grant of benefits case.

In contrast to NTA Graphics, the Board has held in other cases that unions are barred from providing benefits during election campaigns even

117. 52nd St. Hotel Assocs., 321 N.L.R.B. at 635.

118. See Freund Baking Co. v. NLRB, 165 F.3d 929, 930-31 (D.C. Cir. 1999) (describing Board's ruling in an unpublished decision that it was permissible for union to sponsor a suit for overtime before the election); BHY Concrete Finishing, Inc., 323 N.L.R.B. 505 (1997) (allowing union to assist employees with a lawsuit before the election); Nestle Dairy Sys. Inc., 311 N.L.R.B. 987 (1993) (finding unobjectionable union's filing a RICO lawsuit against the employer shortly before the election).

119. See 52nd St. Hotel Assocs., 321 N.L.R.B. at 630-34 (demonstrating that the Board's decision was largely grounded on its conclusions that pursuit of lawsuits to improve employment conditions is protected by the First Amendment and Section 7 of the NLRA).

120. See NTA Graphics Inc., 303 N.L.R.B. 801 (1991).

121. Id. at 803 .

122. Id.

123. Id. at 803-04 n. 14 (citing Mailing Servs. Inc., 293 N.L.R.B. 565 (1989)).

124. Id. at 804 . 
if those benefits are or could be ordinarily extended to union members. ${ }^{125}$ In Wagner Electric, a regional director had found that the life insurance benefits at issue were "merely an incident of membership" that the union was extending to new members. ${ }^{126}$ The Board did not dispute the director's factual finding that the union provided the insurance benefits to its members, but the Board nonetheless overruled the regional director and held that the benefit was a "gift" and therefore objectionable. ${ }^{127}$ More than twenty years later, in Mailing Services, the Board held it objectionable for the union to offer employees pre-election health screenings even though the union often provided such screenings to employees in bargaining units it represented. ${ }^{128}$ The Board found that it did not matter whether the union provided such screenings only to employees for whom it was the exclusive bargaining representative, or to union members generally, because the union was barred from providing benefits to what the Board called "potential members" before an election. ${ }^{129}$ The Board noted that while unions can "promise an existing benefit to new members" or "publicize an existing incident of union membership," the union cannot actually provide membership benefits before the election. ${ }^{130}$

The courts, meanwhile, have unequivocally held that unions cannot provide membership benefits to employee-voters prior to the election. Both the D.C. Circuit and the Sixth Circuit have held recently that unions "may not give voters 'free samples' of benefits before an election." "131 The Sixth Circuit additionally declared that "[i]t is also no defense that the benefit granted could have been routinely extended to Union members." 132

The D.C. Circuit in Freund not only condemned "free samples," but also definitely limited the sphere of relevance both "spatially" and "temporally." ${ }^{133}$ The D.C. Circuit stated that employees' votes should be based "upon an assessment of the merits of union representation," 134 and the court went on to make clear that by "representation" it meant only the union's ministering to employees after the election and within the workplace. ${ }^{135}$ In holding that the union was barred from pursuing a lawsuit on behalf of employees, the court certainly showed that it did not broadly

125. See, e.g., Wagner Elec. Corp., 167 N.L.R.B. 532 (1967); Mailing Servs. Inc., 293 N.L.R.B. 565 (1989).

126. Wagner Elec. Corp., 167 N.L.R.B. at 533.

127. Id.

128. See Mailing Servs., Inc., 293 N.L.R.B. at 565.

129. Id. at 565 .

130. Id. at $565-66$.

131. Comcast Cablevision v. NLRB, 232 F.3d 490, 496 (6th Cir. 2000); See also Freund Baking Co. v. NLRB, 165 F.3d 929, 933 (D.C. Cir. 1999).

132. Comcast Cablevision, 232 F.3d at 496.

133. See Freund Baking 165 F.3d at 935.

134. Id. at 932 .

135. Id. at 935 . 
define "representation" as union service to employees, or even as a union acting as the employees' agent in forums other than workplace dealings with the employer. In addition, though the court observed that the "union's willingness to prosecute a suit" was "relevant" to the election, the court explained this was only because "it helps employees to evaluate the likelihood that representation by a particular union will improve those [employees'] conditions." 136 With this wording, and with Freund's reference to pre-election benefits as "free samples," the D.C. Circuit manifested its view that "representation" was something that would occur in the future, and that union aid to employees before the election and outside the workplace (i.e. in court) was merely a hint of how the union would represent employees after the election. Because the NLRA provides that all Board decisions are subject to appeal to the D.C. Circuit, ${ }^{137}$ the holding in, and reasoning of, Freund has since constrained the Board and other courts from adopting any other position on union benefit grants.

\section{B. The Reality: Employee Considerations Beyond the "Sphere of Relevance"}

The Board's and courts' narrow definition of the "sphere or relevance," limiting it to the union's role in addressing conditions in the workplace only after it has been elected or recognized as the employees' exclusive bargaining representative, erroneously disregards a major dimension of the relationship between unions and employees. As noted at this article's outset, the raison d'être for unions is to assist employees. Moreover, the forms of assistance unions provide to employees are not now, and never have been, limited to the work environment and to representing employees vis-a-vis their employers. History professor Dorothy Sue Cobble has studied the pre-NLRA history of the American Federation of Labor (AFL) and its affiliated unions, and found that "[h]istorically, collective bargaining was one of many methods used by unions to raise the living standards of American workers. Similarly, securing a formal trade agreement with an employer, while desirable, was not the defining feature of unionism. ${ }^{\prime 38}$ Professor Cobble has shown that

136. Id. at 933 (emphasis added).

137. See 29 U.S.C. $\S 160$ (e), (f) (2002). See also Carlin, supra note 3, at 570-71 (positing that the D.C. Circuit's Freund decision effectively closes the door to unionprovided legal representation for employee-voters before an election).

138. Dorothy Sue Cobble, Lost Ways of Unionism, in REKINDLING THE Movement 82, 90 (Lowell Turner et al. eds., 2001). The "lost ways" to which Professor Cobble refers are not the forms of union-provided worker assistance, but rather the organizing, by unions, of the self-employed and unemployed, and the direct affiliation of local unions with the AFL instead of through a parent international. See id. at 87-89. See also Dorothy Sue Cobble, Lost Ways of Organizing: Reviving the AFL's Direct Affiliate Strategy, 36 INDUS. REL. 278 
many unions provided assistance mostly in the form of "benevolent functions," such as "relief to the sick, burial benefits, unemployment assistance, training, and job referrals." 139 A few unions also "set up community arbitration boards to mediate wage and other disputes between individual members and local employers." 140

This union tradition, of providing benefits and assistance to employees outside the work environment, continues to the present day. Several unions still perform the "benevolent functions" they began in the 19th century, by providing workers and their families with illness, disability or death benefits that are funded and paid directly by the union and not through any employer. ${ }^{141}$ Many unions support and staff legal services programs for their members, in which the legal assistance is not primarily for workplace issues, but for matters like real estate transactions, personal bankruptcy, and family law. ${ }^{142}$ Most comprehensively, since 1986 the AFL-CIO and its affiliated unions have offered, through the Union Privilege program, an array of benefits and services to union members and their families. These programs include loans and other financial services, many types of insurance, and a health savings program. ${ }^{143}$

Aside from benefits and services outside the workplace, unions also extend assistance to nonunion employees. An important example is legal representation: Professor Catherine Fisk described union efforts to enforce employment laws in nonunion workplaces as "for most employees ... the most significant role that unions play today," and she identified several

\section{(1997).}

139. Cobble, Lost Ways of Organizing, supra note 138, at 291. See also John Fabian Witt, Toward a New History of American Accident Law: Classical Tort Law and the Cooperative First Party Insurance Movement, 114 HARv. L. REv. 690, 791-95 (2001) (discussing trade union insurance and benefits funds in the late-19th and early-20th centuries).

140. Cobble, Lost Ways of Organizing, supra note 138, at 291.

141. See, e.g., Ellis v. Bhd. of Ry., Airline and S.S. Clerks, 466 U.S. 435, 453-54 (1984) (discussing the union's direct provision of death benefits "rather than seeking them from the employer"); Snyder v. Freight, Constr., Gen. Drivers, Warehousemen \& Helpers, Local No. 287, 175 F.3d 680, 683 (9th Cir. 1999) (describing sick and death benefits provided directly by the union); United Bhd. of Carpenters \& Joiners of Am. v. Tile Helpers Union Local 88, 803 F. Supp. 601, 605 (E.D.N.Y. 1992) (discussing unions' establishment of death and mortuary benefits); Int'l Bhd. of Teamsters, Local 776 (Carolina Freight Carriers Corp.), 324 N.L.R.B. 1154, 1155 (1997) (mentioning union's maintenance of a "death benefit" funded by union dues).

142. See, e.g., UAW Legal Service Plans, available at http://www.uawlsp.com (last visited on July 19,2002) . It is interesting to note that even in 52nd St. Hotel Assocs., where the Board found that "employment-related" litigation was permissible, the Board indicated that legal services for "unrelated" matters like a "divorce proceeding or personal injury lawsuit" would be objectionable. 52nd St. Hotel Assocs., 321 NLRB 624, 635 n.57 (1996). The Board apparently regarded those services commonly offered by unions in legal services plans as being outside the "sphere of relevance".

143. See http://www.unionplus.org (last visited July 17, 2002). 
recent examples of unions and their lawyers representing nonunion workers in litigation. ${ }^{144}$ The United Mine Workers' commitment to provide legal aid to miners, in union and nonunion workplaces, is even enshrined in its constitution. ${ }^{145}$ Unions also assist nonunion workers in other ways. Many unions support and staff twenty-four hour referral systems for workers with emotional and personal problems. ${ }^{146}$ In alliance with educational institutions, unions offer literacy and adult education programs. ${ }^{147}$

These are just some of the multitude of benefits and services that unions provide to employees outside their workplaces. Unions' "extraworkplace" assistance to employees is a vital element of the relationship between unions and workers. Yet the Board and courts have based their decisions in union grants of benefits cases on the principle that extraworkplace benefits must be absent from the employees' consideration when voting in representation elections. ${ }^{148}$

The Board and courts do not completely ignore unions' extraworkplace benefits. Instead, they treat such benefits as something unreal and counterfeit, calling them "samples" or "extraneous." 149 The Board and courts have concluded that these are artificial considerations and have banned extra-workplace benefits during representation elections. ${ }^{150}$ It is only in the Board's and courts' conception, however, that extra-workplace benefits are mere "samples." In the real world, extra-workplace benefits are certainly concrete and important to the workers and their families who receive them. From these workers' points of view, forms of extraworkplace assistance are as real and as important as the union's service as the "bargaining representative" is in the workplace. For workers, for unions, and for society, there is nothing artificial about extra-workplace benefits. Rather, what is contrived and unnatural is the Board's and courts' rule preventing employee-voters from experiencing and appreciating the same kinds of union extra-workplace benefits that thousands of workers already enjoy all around the country.

At the core of the prohibition on union grants of benefits is the apparent assumption that in an NLRB representation election, all that is

144. See Fisk, supra note 4 , at 59 \& nn.7-10.

145. See 52nd St. Hotel Assocs., 321 N.L.R.B. at 629.

146. ARTHUR B. SHOSTAK, RobUST UNIONISM 141 (1991).

147. Id. at 158-61. See also Samuel Leiken, New Jobs for Labor Unions, N.Y. TimES, Aug. 31, 2002, at A15 (advocating that union greatly expand their role in providing educational and career guidance services to nonunion employees).

148. See supra notes 116-129 and accompanying text (discussing Board and court decisions limiting the "sphere of relevance" in union elections to what unions can do within the workplace environment).

149. See Comcast Cablevision, 232 F.3d at 496; Freund Baking Co. v. NLRB, 165 F.3d at 933; NLRB v. L \& J Equip., 745 F.2d 224, 321 (3d Cir. 1984).

150. See supra notes 116-129 and accompanying text. 
relevant to voters is the kind of workplace representative the union will be for them. While this is a plausible theory, in actuality it is incorrect. The assumption posits that when employees prepare to vote, all they need to know and think about is what the workplace will be like if the union wins. Employees, though, should have the right to know and even experience what their lives will be like, in and out of the workplace, if the union wins.

The current law on union grants of benefits imposes an unrealistic barrier between what unions do for employees inside the workplace and what they do for employees outside the workplace. Such compartmentalization simply does not exist in the real world. First, a union's function of representing employees in the workplace and providing other forms of assistance beyond it are interrelated. A union's capacity to provide extra-workplace assistance to employees is considerably enhanced by attaining representative status. Without representative status, a union usually has no right to access the workplace ${ }^{151}$ or to obtain information from the employer. ${ }^{152}$ With representative status, a union acquires rights both to access and information, ${ }^{153}$ which greatly improves a union's ability to find out what kinds of extra-workplace assistance employees desire and need. The Union then can deliver that assistance to workers. In addition to augmenting a union's legal rights, the attainment of representative status almost certainly raises the union's esteem among employees, and hence makes them more receptive to obtaining extra-workplace assistance from the union.

The law does not absolutely prohibit unions from providing extraworkplace benefits to employees they do not represent; the ban ostensibly applies only during the "critical period" between the filing of an election petition and the actual election day. The D.C. Circuit emphasized this time limit in Freund in rejecting the Board's argument that Section 7 of the NLRA entitled the union to pursue a lawsuit on behalf of employees. The court responded that " $[\mathrm{u}]$ nder the Act contestants in a representation election are routinely prevented from exercising certain rights during the brief time when their exercise might interfere with the voters' free choice." 154

There are several flaws with the argument that the ban on extraworkplace benefits is reasonable because of its limited duration. First,

151. See Lechmere, Inc. v. N.L.R.B., 502 U.S. 527, 535 (1992).

152. See Hardin, supra note 2, at 673 (no duty arises until the union becomes the bargaining representative).

153. Regarding the right of access to the workplace, see, e.g., New Surfside Nursing Home, 330 N.L.R.B. 1146 n. 1 (2000); C.C.E., Inc., 318 N.L.R.B. 977 (1995); Holyoke Water Power Co., 273 N.L.R.B. 1369 (1985), enforced, 778 F.2d 49 (1st Cir. 1985). See also Hardin, supra note 2, at 650-85 (regarding the right to obtain information from the employer).

154. Freund, 165 F.3d at 934 (emphasis added). 
contrary to the D.C. Circuit's characterization, the critical period is often not "brief;" Professor Fisk has shown that the critical period frequently lasts several months, or even longer when there are rerun elections. ${ }^{155}$ Moreover, as Professor Fisk also points out, the Board and courts have not rigorously restricted the ban's application to the critical period, and have commonly set aside elections based on benefits offered prior to the filing of the election petition. ${ }^{156}$ In addition, even when the ban is limited to the critical period, it generates many practical problems. For example, as the Board itself recognized in 52nd Street Hotel Associates, the ban effectively makes legal assistance impossible at any time. If a lawsuit were filed before the critical period begins, actions to maintain the lawsuit would necessarily continue into the critical period, and if the suit was filed after the election, preparation for the suit would have to occur during the critical period. ${ }^{157}$

As the example of legal assistance demonstrates, prohibiting grants of benefits, even if just during the critical period, acts to cut off employees from ongoing receipt of union assistance. Since 1985, the AFL-CIO and several of its affiliate unions have provided "associate memberships" to unrepresented employees, through which such employees enjoy the benefits of credit cards and various types of insurance. ${ }^{158}$ For unions to comply with the law on grants of benefits, whenever a union conducts an organizing effort at a workplace with one or more associate members, the union would have to take steps such as suspending those members' insurance or canceling their credit cards, thus causing serious inconvenience or worse to those workers and their families. As already mentioned, when unions are pursuing lawsuits for nonunion employees ${ }^{159}$ and this interaction leads to organizing activity, current law would require the union to drop the lawsuit. For the union's lawyers, this would constitute an ethical violation. ${ }^{160}$ Such possibilities are not mere hypotheticals: union extra-workplace assistance to unrepresented employees often spurs those employees to explore having the union also become their representative.

155. Fisk, supra note 4 , at $67 \& n .47$ (citations omitted).

156. See id. at $67 \&$ n. 48 (citations omitted). Even in Wagner Electric, the seminal case on prohibiting union grants of benefits, the Board found benefits that the union proffered before the election petition was filed objectionable. See Wagner Electric, 167 N.L.R.B. at 532 (referring to benefits offered on Feb. 2, 1967).

157. See 52nd St. Hotel Assocs., 321 N.L.R.B. at 638-39. See also Carlin, supra note 3, at 564 (discussing the Board's reasons for rejecting a "bright line rule" barring lawsuits only during the critical period).

158. See Bill Leonard, The New Face of Organized Labor, 44 HR Magazine 54, July 1, 1999; "AFL-CIO Council Will Receive Report on 'Associate Memberships,"” 23 Daily Lab. Report (BNA) A-6 (Feb. 4, 1986).

159. See supra notes $143-44$ and accompanying text (discussing examples of suits that unions and their lawyers have litigated for unrepresented employees).

160. See Fisk, supra note 4, at 91. 
The current prohibition effectively forces such employees to make a difficult and unreasonable choice between their continued receipt of union assistance and exercise of their Section 7 right to have a union as their workplace representative.

In this way, the current prohibition on union grants of benefits stands as a major obstacle to improving the lives of millions of workers and their families. To take an especially timely example, unions could make various forms of insurance available to workers at much lower cost than they could obtain individually. Unions band thousands of individuals into pools that lessen the risk to insurers, which in turn leads the insurers to lower their premiums. ${ }^{161}$ In a time when the number of Americans without health insurance is often called a "crisis,", variety of approaches to address, ${ }^{163}$ it simply makes no sense to retain a rule that deters unions from offering insurance to the uninsured.

Another current crisis that unions could help solve is the growing gap between the new skills required in the American economy and the "older" skills actually possessed by many American workers. ${ }^{164}$ Many commentators have observed that unions are in an excellent position to supply the training and skills-building that millions of workers need. ${ }^{165}$

161. See, e.g., Witt, supra note 136, at 791-92 (explaining that union accident insurance plans can overcome adverse selection and moral hazard problems); Greg Tarpinian, Labor's New Health Care Option, IN THESE TIMES, Mar. 3, 1997, at 10 (discussing how pooling of purchasing power enables unions to purchase insurance on more favorable terms).

162. See, e.g., Jonathan Riskin, Health Coverage Heats Up as Issue: Millions in U.S. Lack Insurance, Which Could Be a Hot Political Topic, Columbus DisPaTCH, July 15, 2002, at 01A; Peter Deutsch, Solving the Uninsured Crisis, WASH. Times, July 28, 2000, at A15; Robert Kuttner, Incremental Reform Toward What, AM. PROSPECT, Feb. 14, 2000, at 4; Jeanne Schulte Scott, The Once and Future Healthcare Crisis, HEALTHCARE Fin. MGMT., July 1998, at 26 (discussing the "coverage crisis" in health insurance).

163. See, e.g., Help for America's Uninsured Act of 2001, H.R. 647, 107th Cong. (2001) (allowing tax payers to donate portions of their tax refund toward catastrophic care for the uninsured); Medi-Access Act of 2001, H.R. 1142, 107th Cong. (2001) (proposing uninsured individuals obtain coverage under the Medicaid program); Health Insurance Affordability and Equity Act of 2001, H.R. 1181, 107th Cong. (2001) (proposing incentives for private health coverage for the previously uninsured).

164. See, e.g., David T. Ellwood, Worksheet for Labor, WASH. Post, Sept. 2, 2002, at A23 (contending that because of a growing skills shortage, "[b]usiness and government must make an unprecedented commitment to develop new training and skills-building strategies"); U.S. Department of Labor, Employment and Training Administration, H-1B Technical Skills Training Grants, 66 Fed. Reg. 64859 (Dec. 14, 2001) (announcing the availability of skills training grants and explaining that "[t]he grants are intended to be a long-term solution to domestic skill shortages in high skill and high technology occupations"); Clay Wilson, IT Workers Shortage: Implications for Education Policy, POL'Y STUD. REV., Sept. 2001, at 167 (discussing "an increasing gap between business demand for and growth in the supply of Information Technology (IT) workers").

165. See, e.g., Leiken, supra note 144; Katherine V.W. Stone, Employee Representation in the Boundaryless Workplace, 77 CHI.-KENT. L. REV. 773, 808 (2002) (advocating a greater role for unions in training workers as employees increasingly move from employer 
Again, however, the prohibition on union benefit grants acts as a serious deterrent, because it requires unions to suspend or terminate these training services if the union also explores organizing these workers. In preventing unions from playing a larger role in solving these and other serious problems, the rule against union benefit grants actually harms society as a whole.

This harmful prohibition is not required by the National Labor Relations Act; indeed, it is inconsistent with that Act's fundamental purpose of enhancing employees' freedom of choice regarding representation. Under the prohibition, employees involved in an organizing campaign are not allowed to receive union extra-workplace assistance, or if they are already receiving it, the union must take it away. This means that employees are either forced to cast their ballots without having experienced what it is like to be assisted by a union, or with the bitter experience of having had such assistance stripped away. Thus, contrary to the assertion that union benefit grants "pervert the employees' free choice", ${ }^{166}$ it is the prohibition on benefit grants that interferes with choice. The prohibition artificially minimizes the experience employees can have of union assistance and thus skews employees' perceptions of how a union can benefit them. Justice Byron White recognized this effect in his dissent in Savair, contending:

The Court cannot ignore the fact, as well, that $\S 1$ of the National Labor Relations Act declared the congressional policy of "encouraging the practice and procedure of collective bargaining." 29 U.S.C. § 151 . The existence of unions is an inescapable corollary of this preference. To the extent that this Court prohibits the union from promising a fairer deal for unionized employees by describing the benefits to be obtained by unionization, this policy is seriously eroded. This Court has often underscored this preference in the Act. This preference is only one of opportunity and the free choice of the employee must be protected, but restrictions on the communications of the union as to potential benefits may unduly prevent the intelligent exercise of such choice. ${ }^{167}$

The prohibition on grants of benefits does impair the employees' "intelligent exercise" of their choice by lessening their awareness and understanding of what a union can do for them.

to employer); Eileen Silverstein \& Peter Goselin, Intentionally Impermanent Employment and the Paradox of Productivity, 26 STETSON L. REv. 1, 57 (1996) (proposing that unions create employment offices to train workers and help find them jobs).

166. NLRB v. Whitney Mus. of Am. Art, 636 F.2d 19, 22 (2d Cir. 1980).

167. NLRB v. Savair, 414 U.S. 270, 285 n.4 (1973) (White, J., dissenting) (emphasis added) (citations omitted). 
Many employers take full advantage of this gap in employee understanding and thus exacerbate the deleterious effects of the ban on union benefit grants. A popular theme that employers use against unions in election campaigns is telling employees the union can do nothing meaningful for them or can offer them nothing but "empty promises." Even among the representation campaigns that are discussed in Board decisions, which are just a small fraction of the thousands of representation campaigns conducted every year, ${ }^{168}$ there are scores of cases in which employers attacked unions with these themes. Employers have made these arguments to employees both in written communications ${ }^{169}$ and in speeches. ${ }^{170}$ Many employers also bolster the attack by contrasting the "nothing" available from unions with the hard cash that employees will have to pay to the unions in the form of dues. ${ }^{171}$ Of course, employers never disclose to employees that the law prevents unions from giving them anything more tangible than these promises. Thus, if a union tells employees about the extra-workplace assistance that it provides to

168. See, e.g., Number of Union Elections Down in 2001, 116 Daily Lab. Rep. (BNA) C1 (June 17, 2002) (reporting that there were more than 2300 representation elections in 2001).

169. See, e.g., Aircap Mfgs., a Div. of Sunbeam Corp., 287 N.L.R.B. 996, 1017 (1988) (involving employer letter that told employees to "make a decision on the truth and not on empty promises"); Diner's Drive-In, Inc., 280 N.L.R.B. 971, 973 (1986) (involving a letter from owner to employees that said, "we serve the customers with food - a necessity of life all the union serves is empty promises and disasters"); Progressive Supermkts., Inc., 259 N.L.R.B. 512, 520 (1981) (involving a letter to employees that stated, "Don't be misled by empty union promises. The union cannot guarantee you a single thing."); Douglas Div., The Scott \& Fetzer Co., 228 N.L.R.B. 1016, 1019-20 (1977) (involving a letter that told employees to be wary of "any empty promises that might come from the union"); Bostitch Div. of Textron, Inc., 176 N.L.R.B. 377, 382 (1969) (involving a letter to employees that said, "[T]he union has made "pie-in-the-sky" promises. Their promises are empty ones, since they have no ability to carry them out.").

170. See, e.g., Palagonia Bakery Co., Inc., 2001 N.L.R.B. LEXIS 906, at *17 (Nov. 2, 2001) (involving employer who told employees at pre-election meeting "that the union will not do anything 'serious' for the employees"); State Materials, Inc., 328 N.L.R.B. 1317, 1320 (1999) (involving a management official who told employees that the union is "not going to do anything for you"); Atlantic Forest Prods., Inc., 282 N.L.R.B. 855, 871 (1987) (involving a manager who told employees that, "[w]hat you'll be voting on is not whether you like the sound of fancy union talk but whether you are willing to risk your steady job and paycheck and the welfare of your family and this community on empty promises").

171. See, e.g., Menlo Food Corp., 330 N.L.R.B. 337, 341 (1999) (involving a letter to employees one week before election that stated, "A lot has been said by the union about what they can do for you. They have made a lot of promises, but can they deliver ...? A sound and profitable business will provide job security. Not empty promises as the union has been telling you ... if [the union] want[s] to charge you monthly dues, assessments and fines, they should give you a guarantee as to what you will receive in return for your money."); Flamingo Hilton-Laughlin, 324 N.L.R.B. 72, 80 (1999) (involving a memorandum to all employees that said, "You do not need a Union, which won't do anything for you and which will cost you a lot of money."). 
employees, the employer can deride those explanations as "empty promises," and the law prevents the union from correcting that inaccurate message by giving the employees any real benefits or services during the campaign.

Like a union, an employer is prohibited from granting benefits during the election campaign, but an employer has more opportunities than any union to provide employees benefits prior to the election campaign. The reasons are obvious: the employer always has a relationship with its employees before the union can even begin to contact them, and the employer is in a position to give its employees desired benefits nearly every day. Many employers rely heavily on these opportunities to resist unionization. Employers often change wages, benefits or other employment terms with the primary motivation of influencing employees to choose not to unionize. ${ }^{172}$

During union elections campaigns, all employers remind employees of any benefits they have provided them, but many employers also use benefit-related themes that depend on the union's inability to provide benefits during the campaign. For example, a number of employers that use the "empty promises" attack strengthen it by contrasting the union's failure to do anything concrete with the employer's record of providing tangible employment benefits. ${ }^{173}$ An even more popular theme, recommended by management consultants, is for employers to invoke present or past benefits while making appeals to employees' loyalty or gratitude. ${ }^{174}$ Given that employers are freely allowed to make those sorts of appeals, the notion that union benefits must be barred to prevent any "sense of obligation" in employees can fairly be called risible.

Employers can and do take advantage of the prohibition on union

172. See, e.g., William A. Whiteside \& Marvin L. Weinberg, Coping with the Unionization Drive: A Guide for the Careful Employer, PRAC. LAW., Dec. 1997, at 45.

173. See, e.g., The Cambridge Wire Cloth Co., 256 N.L.R.B. 1135, 1141 (1981) (involving a flyer distributed to employees that told them not to "trade proven company performance for empty promises"); CHARLES L. HUGHES, MAKING UNIONS UNNECESSARY 16 (1976) (recommending to employers that when holdings meetings with employees during the representation campaign, they ask employees to respond with a show of hands to questions like: "Did the union get you your job?" "Can a union keep your job?" "Has a union gotten you the pay increases that you've had in the past?").

174. See, e.g., MARTIN JAY LeVITT \& TERRY CONROW, CONFESSIONS OF A UNION BUSTER 96 (relating story of employer who cynically told employees, "We're family"); JOHN J. LAWLER, UNIONIZATION AND DEUNIONIZATION 149 tbl.7.3 (1990)(showing employer use of "procompany" themes in campaigns, including "[m]anagement is a friend to workers" and "[w]orkers already enjoy high wages and/or good working conditions"); ALFRED T. DeMaria, How Management Wins Union ORganizing Campaigns 106 (1980) (recommending that employer's communications to employees include an explanation of existing benefits, "from the most important down to ... company picnics, bowling leagues, and Christmas parties"); Diner's Drive-In, Inc., 280 N.L.R.B. 971,973 (1986) (involving letter that pleaded with employees to "stick by your Company and vote 'No"'). 
benefits to convey a misleading message to employees that unions can do nothing tangible for them and can only make promises that will be unrealized. Unions should be permitted to correct (or forestall) this wrong impression by making real benefits available to employees during the campaign. Union grants of benefits would also promote more balanced elections by providing some counterweight to employer invocations of the employer-provided benefits that employees have enjoyed over the years.

The prohibition on union grants of benefits is all the more peculiar when compared with the law on union promises of benefits. In making promises to voting workers, unions are not limited to promising benefits that may be obtained through bargaining, ${ }^{175}$ but can also promise extraworkplace benefits such as free legal services, ${ }^{176}$ generous strike benefits ${ }^{177}$, post-retirement medical services, and other benefits "irrespective of the results of bargaining." ${ }^{178}$ As demonstrated by this list, unions are free to promise benefits that are condemned in grant-of-benefits cases. ${ }^{179}$

The law does place a limit on union promises of benefits, but the restriction is far more reasonable and realistic than in grants of benefits cases. In their decisions on promises of benefits, unlike those on grants of benefits, the Board and courts have recognized the fact that unions provide assistance to employees both inside and outside the workplace. Accordingly, unions are permitted to promise "the extension of existing membership benefits to employees." ${ }^{\prime 180}$ In other words, when a union has a practice of providing a form of assistance to its members, the union can promise the same type of assistance to employee-voters during an election campaign. A union cannot promise benefits that are "newly created," 181 on an ad hoc basis, only for a given election and made contingent on the union's ability to win the election. Under this rule, it's been found objectionable for a union to promise employees that, if the union wins, it

175. See, e.g., DLC Corp., 333 N.L.R.B. No. 79, 166 L.R.R.M. (BNA) 1367 (2001); Station Operators, Inc., 307 N.L.R.B. 263 n.1 (1992).

176. See, e.g., Colquest Energy v. NLRB, 965 F.2d 116, 121 (6th Cir. 1992); Hallandale Rehabilitation and Convalescent Center, 313 N.L.R.B. 835, 836 n.6 (1994); Dart Container, 277 N.L.R.B. 1369,1369 n.7 (1985).

177. See, e.g., Lloyd A. Fry Roofing Co., 119 N.L.R.B. 661, 662 (1957).

178. See, e.g., Sports Shinko Corp., 316 N.L.R.B. 655, 667-68 (1999).

179. Compare Dart Container, 277 N.L.R.B. at 1369 n.7 (allowing promise of free legal services) with Freund Bakery Co. v. NLRB, 165 F.3d 928, 932-35 (D.C. Cir. 1999) (barring union grant of free legal services); compare Sports Shinko, 316 N.L.R.B. at 667 (allowing promise of medical benefits) with Wagner Electric Corp., 167 N.L.R.B. 532, 533 (1967) (barring union grant of life insurance benefits).

180. Trencor, Inc. v. NLRB, 110 F.3d 268, 273-74 (5th Cir. 1997); see also Sports Shinko, 316 N.L.R.B. at 668; Mailing Serv., 293 N.L.R.B. at 565; Dart Container, 277 N.L.R.B. $1369,1370$.

181. Dart Container, 277 N.L.R.B at 1370. 
will hold a raffle for $\$ 100,{ }^{182}$ or "the biggest party in the history of Texas." ${ }^{\text {"183 }}$ Thus, the law says it's acceptable for unions to promise regular benefits (e.g. legal services, insurance benefits) that are typically provided to members, but not other benefits (e.g. massive parties, money raffles, cash payments) that most unions do not generally give to members. This demarcation is based upon the realities of union-employee relationships. ${ }^{184}$

Nearly the same line is drawn for grants of benefits by employers during election campaigns. When an employer is charged with objectionable conduct or an unfair labor practice for providing benefits, the employer can raise as a defense that it has a past pattern or practice of granting this benefit at regular intervals or at roughly the same time every year. ${ }^{185}$ If the equivalent rule were applied to the union side of the campaign, unions should be able to provide to employee-voters any benefits the union has a "pattern or practice" of giving to their members. ${ }^{186}$ Indeed, management lawyers Charles C. Jackson and Jeffrey S. Heller, in their important article on employer promises and grants of benefits, "presum[ed] the same defenses would be available to the union as to the employer, i.e. that benefits conferred were part of the union's pattern of organizing ...."187 In fact, however, unions are not afforded the "pattern or practice" defense: as discussed earlier, the Board and courts have held that unions during election campaigns are barred from providing even those benefits that they normally provide to their members. ${ }^{188}$ As a review of the law on promises of benefits and employer grants of benefits makes clear, the prohibition on union benefit grants is not only unrealistic and illogical, but also an aberration when compared with rules on similar conduct.

The rule for union grants of benefits should be the same as the rule governing union promises of benefits, and logically equivalent to the rule

182. Crestwood Manor, 234 N.L.R.B 1097 (1978).

183. Trencor, 110 F.3d at 270.

184. Professor Catherine L. Fisk has also advocated that in election campaigns the kinds of benefits that unions ordinarily provide should be permitted, while cash payments should not. Professor Fisk compares this distinction to the one that exists in general political campaigns: "It would be impermissible for legislators to buy votes for cash, but certainly it is not wrong for the legislators to offer assistance with government agencies or other forms of constituent service (as long as the legislator of course does not abuse her power in doing so)." See Fisk, supra note 4, at 91.

185. Jackson \& Heller, supra note 10 , at $18 \& \mathrm{nn} .78-82$, and cases cited therein.

186. Unlike employers, unions in election campaigns do not typically have a longstanding relationship with the employees in the election unit, so a union would never have a "pattern" of providing benefits to employees in that unit. Consequently, the parallel union "pattern" would have to be the union's practice of providing the benefit to employees with whom the union does have an established relationship, i.e., employees who are members of or represented by the union.

187. Jackson and Heller, supra note 10, at 24 n.106.

188. See supra notes $124-31$ and accompanying text. 
on employer grants of benefits. A union should be permitted to provide employees any "existing incidents of membership," that is, benefits or services that the union has a practice of providing to its "members."

"Members" for this purpose should not be taken literally. Under the National Labor Relations Act, "membership" at most means that the employee has fulfilled any obligations to pay dues, and unions cannot impose any other conditions for membership, such as formally enrolling in the union or attending union meetings. ${ }^{189}$ Accordingly, if a union wishes to extend "existing incidents of membership" to employees it is organizing, the law should not require these employees to expressly join or enlist in the union in some way. The employees also should not be required to pay dues in order to become entitled to the benefit, because the law allows unions to waive fees and dues until after an election or even negotiation of a first contract. ${ }^{190}$ Thus, when unions provide employees with benefits that are "existing incidents of union membership," unions can and should provide those benefits unconditionally, without requiring recipients to also become union members.

This approach to union grants of benefits is not wholly without precedent. In 1991, the Board, in NTA Graphics, correctly held that unions should not be found to have "interfered with an election merely by providing to its new members, even during the critical period, benefits to which they would normally be entitled by virtue of their union membership." "191 Even more interestingly, in the first case in which the Board found a union's unconditional grant of benefit to be objectionable, the Regional Director's decision reviewed by the Board actually analyzed the issue correctly. The Regional Director reasoned that the life insurance policy offered by the union "was merely an incident of membership and [the union] would be remiss if it did not extend to new applicants the benefits to which all members were entitled." ${ }^{\prime 92}$ The Regional Director then explained that "the sole difference between the affected employees here and other members of [the union] is that for a limited period of time they were not obligated to pay union dues and initiation fees, an inducement held to be harmless" under the Board's waiver of dues policy, ${ }^{193}$ which has since been endorsed by the Supreme Court in Savair. ${ }^{194}$ The Regional Director discerned that when a union provides extraworkplace benefits to unorganized employees, the union is treating them as it does its other members, except that (as the law permits) it is not requiring

189. See NLRB v. General Motors, 373 U.S. 734, 735 (1963).

190. See supra notes 85-87 and accompanying text.

191. NTA Graphics, 303 N.L.R.B. 803, 804 (1991).

192. Wagner Electric, 167 N.L.R.B. at 533.

193. Id.

194. Savair, 414 U.S. at 273 n.4. 
them to pay dues.

Unfortunately, the Board in Wagner Electric failed to grasp the Regional Director's insight, apparently distracted by its perception that the union's "gift" of life insurance was "most unusual."195 The Board in Wagner Electric chose the wrong course, and the courts followed suit at the expense of employees over the years. Tens of thousands of employees (or more) not only missed out on receiving union benefits and services, but they were also deprived of making a fully informed election choice based on everything the union could do to change their lives. In order to truly protect employee freedom of choice, the Board must change the law to allow unions to provide unrepresented employees the kinds of assistance that the union has a practice of providing to its members.

\section{IV. "GoOSE AND GANDER?": THE REASONABLENESS OF REMOVING THE BAN ON UNION GRANTS OF BENEFITS WHILE THE BAN ON EMPLOYERS REMAINS}

The Board and courts have often referred to the ban on union grants of benefits as being equivalent to the rule prohibiting employer grants of benefits during election campaigns. In the seminal Wagner Electric decision, the Board opined that "[i]t is our view that the gift of life insurance coverage to the prospective voter is more akin to an employer's grant of a wage increase in anticipation of a representation election than it is to a waiver of union initiation fees and that it subjects the donees to a constraint to vote for the donor union."196 More than twenty years later, the Board in Mailing Services paraphrased Wagner in declaring that "a Union's actual grant of benefits to potential members during the critical period is 'akin to an employer's grant of a wage increase in anticipation of a representation election... [which] subjects the donees to a constraint to vote for the donor union." "197 The Sixth Circuit in turn asserted in Comcast Cablevision that “[i]n Mailing Services, the Board equated a union's grant of free medical screening during the critical period with an employergranted wage increase." 198 Summing up these comparisons, Board Member Cohen in dissent in $52^{\text {nd }}$ Street Hotel Associates declared, "The Board has long equated union grants of benefits during the critical period with employer grants of a wage increase during that period, and found them objectionable. [Citing Wagner Electric, Mailing Services]. In short, according to precedent, what is sauce for the goose is sauce for the

195. Wagner Electric, 167 N.L.R.B. at 533.

196. Id.

197. Mailing Servs., 293 N.L.R.B. 565, 565 (1989)(ellipsis in original)(quoting Wagner Electric, 167 N.L.R.B. at 533).

198. Comcast Cablevision, 232 F.3d at 496. 
gander.",199

In a sense, the Board and courts know better. The reasons for prohibiting employer grants of benefits are very different than the reasons for prohibiting grants by unions. The central basis for barring unconditional benefits by employers is that they are an implied threat to employees. As the Supreme Court famously said in Exchange Parts, employer benefits are a "fist inside the velvet glove" and "[e]mployees are not likely to miss the inference that the source of benefits now conferred is also the source from which future benefits must flow and which may dry up if it is not obliged." 200

By contrast, unions simply are not in a position to use unconditional benefits to threaten employees in the way that employers have been found to do. As Justice White observed in his dissent in Savair, "in the union context, the fist is missing ... since [a union] was not the representative of the employees, and would not be if it were unsuccessful in the election, [it] could not make the same threat by offering a benefit which it would take away if it lost the election.,201 In Savair, the Supreme Court majority found that a union could threaten employees with conditional benefits (i.e. benefit provided in return for employee signing a card), but neither the Board nor any court have ever held that a union's providing an unconditional benefit was threatening to employees. On the contrary, the Board established in Primco Casting ${ }^{202}$ that the "implied threat" rationale does not apply to union grants of benefits. The Board expressly distinguished Exchange Parts on the ground that " $[t]$ his coercive element, the presence of an implied threat of future reprisal cannot properly be found to be present where a union takes action such as the [union] took here to improve its agency relationship with employees... For, as the employees are aware, if the union is not obliged - that is, if it loses the election, it can have no effect on the employees in the future whatsoever." ${ }^{203}$ In sum, the Board and courts have already realized that the prohibitions on grants of benefits for employers and unions are not truly equivalent.

One significant way in which the prohibitions differ is in the Board's authority to revise them. As explained earlier, the Supreme Court has never ruled that unconditional union grants of benefits are illegal or objectionable. ${ }^{204}$ By contrast, the Court in Exchange Parts did hold that

199. 52nd St. Hotel Assocs., 321 N.L.R.B. at 642 (Cohen, Member, dissenting).

200. NLRB v. Exchange Parts Co., 375 U.S. 405, 409 (1964).

201. Savair, 414 U.S. at 285 (White, J., dissenting).

202. Primco Casting Corp., 174 N.L.R.B. 244, 244 (1969).

203. Id. at 245 .

204. See supra note 11 and accompanying text (explaining that the Supreme Court's only decision on union benefit grants, Savair, concerned conditional benefits that were provided only to employees who signed a union authorization card). 
employer promises and grants of benefits during representation campaigns were unfair labor practices and sufficient grounds for overturning the election. ${ }^{205}$ The Court's rulings on these issues are, of course, binding on the Board and lower courts. Indeed, the Supreme Court has commanded the Board and lower courts to adhere to its labor law precedents. ${ }^{206}$ Hence, the rule against employer promises and grants of benefits will stand unless changed by the Supreme Court or Congress.

Given that the prohibition on employer grants of benefits will remain in effect, can it be reasonable for the Board to lift the same ban on unions? After all, many of the criticisms of the rule against union grants of benefits, especially the criticisms discussed in Part II. B. ${ }^{207}$ also logically apply to employer grants of benefits during election campaigns. If the Board, as advocated in this article, explores repealing the prohibition on union grants of benefits, the Board will probably have to consider whether it is reasonable to remove that bar while the restriction on employer benefit grants remains in place.

The disparity in treatment between employers and unions would certainly not be unprecedented. On the contrary, it is common for rules governing organizing campaigns to permit unions to engage in conduct that is forbidden for employers. For example, in 1999 the Board reaffirmed its position that employers are barred from photographing or videotaping employees engaged in organizing activities, even though unions are permitted to do both. ${ }^{208}$ Similarly, while employers generally are prohibited during organizing campaigns from polling or even asking their employees if they support the union, unions are allowed to make such inquiries and even to measure their support among the workforce. ${ }^{209}$ Most relevantly to the grants of benefits issue, unions are permitted to promise employees benefits during organizing campaigns, while employers are forbidden from making such promises. ${ }^{210}$ The Board in Randell Warehouse explained the basic reason underlying all these situations where the law

205. See Exchange Parts, 375 U.S. at 405 .

206. Lechmere, Inc. v. NLRB, 502 U.S. 527, 536-37 (1992). See also Susan K. Goplen, Note, Judicial Deference to Administrative Agencies' Legal Interpretations after Lechmere, 68 Wash. L. Rev. 207 (1993)(explaining that Supreme Court made clear in Lechmere that the Board and lower courts were required to obey Supreme Court precedents when interpreting the NLRA).

207. See supra notes 56-69 and accompanying text (e.g. evidence that grants of benefits do not affect most voters' motivations).

208. Randell Warehouse of Arizona, Inc., 328 N.L.R.B. 1034, 1034 (1999).

209. See, e.g., Kusan Mfg. Co. v. NLRB, 749 F.2d 362, 365 (6th Cir. 1984), in which the court upheld the Board's policy of treating union polling more favorably than employer polling. Interestingly, the Sixth Circuit rejected the employer's contention that "what is sauce for the goose is sauce for the gander." See id. at 364-65.

210. See Hardin, supra note 2, at 115-18 (promises of benefits by employers prohibited) and 366 (promises of benefits by unions generally permitted). 
proscribes employer conduct but permits the same type of conduct by unions: "The Board and the courts... have long applied differing standards to certain types of employer and union conduct during election campaigns in recognition of the fundamental fact that an employer, unlike a union, has virtually absolute control over employees' terms and conditions of employment." 211

The fundamental fact that the employer controls the workplace also underlies some possible justifications for continuing the ban on employer grants of benefits even if the prohibition for unions is repealed. One such justification, already discussed, is that employer grants of benefits can be threatening to employees in ways that union benefit grants are not. ${ }^{212}$ This is not because unions are more benevolent than employers, but because a union that loses a representation election stands in a much different relation to employees than an employer that "loses" an election by having its employees vote in a union. When a union loses an election, it has no presence in the workplace. The employer need not and in fact cannot deal with the union, ${ }^{213}$ the employer can and probably will exclude the union from its property, ${ }^{214}$ and the union cannot even try again in another election for at least one year. ${ }^{215}$ The union could take away "extra-workplace" benefits that it provided to the employees, though there may well be contractual or other legal limits on doing so, ${ }^{216}$ but there is no way that the union could make employees worse off than they were before the union was elected. By contrast, an employer will continue to exert primary control over a workplace even after a union wins an election, and an employer can use that control to make employees worse off in innumerable ways.

The Supreme Court in Exchange Parts, in addition to holding that employers could use benefit grants to threaten employees, also found that

211. Randell Warehouse, 328 NLRB at 1037.

212. See supra notes $196-99$ and accompanying text.

213. See Hardin, supra note 2, at 323-34 (explaining that when a union is not supported by a majority of employees, it is illegal for the employer to bargain with that union or in any way treat it as the employees' representative).

214. See generally Cynthia L. Estlund, Labor, Property, and Sovereignty After Lechmere, 46 STAN. L. REV, 305 (1994)(discussing employers' exercise of their right to exclude union representatives from their property).

215. See 29 U.S.C. $\$ 159(\mathrm{c})(3)$ (1994) ("[n]o election shall be directed in any bargaining unit or any subdivision within which in the preceding twelve-month period, a valid election shall have been held.").

216. For example, as explained previously, when union lawyers are pursuing lawsuits on behalf of employees, it would be a breach of ethics for them to withdraw representation when the union loses an election. See supra note 156 and accompanying text. Also, when a union enrolls employees in insurance plans, training programs, or other benefit programs, the employees may become parties to a contract, and thus entitled to continued receipt of these benefits. 
employers could use them to trick employees. ${ }^{217}$ The Court explained that its ruling would not discourage true improvements for employees because "[t]he beneficence of an employer is likely to be ephemeral if prompted by a threat of unionization which is subsequently removed. Insulating the right of collective organization from calculated good will of this sort deprives employees of little that has lasting value. ${ }^{, 218}$ In other words, if allowed, an employer could grant employees benefits during an election campaign to induce employees to vote against the union, and then after the union's loss the employer could remove those benefits or make up the cost of those benefits through reductions elsewhere.

Although unions could also trick employees by granting them benefits before an election and retracting them after the union wins the election, unions have greater disincentives to do that than employers do. While retaining the good will of its employees is no doubt valuable to an employer, it is absolutely essential to a union. Under the law, a union cannot be the representative of a unit of employees unless it is supported by a majority of the employees in that unit. ${ }^{219}$ If a majority of employees inform an employer they no longer want the union as a representative, the employer can withdraw recognition of that union and cease dealing with it as a representative. ${ }^{220}$ Currently, under the Board's certification bar rule ${ }^{221}$, unions are protected from withdrawal of recognition for the first year after winning an election, but that could change. Congress has considered a bill that would eliminate the certification bar, ${ }^{222}$ and the Board certainly has the authority to modify or waive that bar in the case of unions that trick employees by retracting benefits. Moreover, for any union that tricks employees and loses their support as a result, the certification year will

217. See Exchange Parts, 375 U.S. at 409. Federal appeals courts and the Board have recognized that this is an additional rationale the Supreme Court relied on in prohibiting employer grants of benefits. See, e.g., Russell-Newman Mfg. Co. v. NLRB, 407 F.2d 247, 252 (5th Cir. 1969); Great Plains Steel Corp., 183 N.L.R.B. 968, 977 (1970). However, in Skyline Distributors, concurring judge Karen LeCraft Henderson questioned the majority's statement that the Supreme Court in Exchange Parts "had more than one 'premise' or made more than one 'argument'," and she asserted that "[t]he Court's concern was with an employer who grants employee benefits with the purpose of affecting the outcome of a representation election." Skyline Distribs. v. NLRB, 99 F.3d 403, 408 (D.C. Cir. 1996) (Henderson, J., concurring)(citations omitted).

218. Exchange Parts, 375 U.S. at 410.

219. See 29 U.S.C. \& 159(a). See also Int'l Ladies Garment Workers Union v. NLRB, 366 U.S. 731 (1961) (holding that it is illegal for an employer to recognize a union as the representative of its employees before that union is supported by a majority of those employees, and it is also illegal for such a "minority" union to accept such recognition).

220. See Levitz Furniture, 333 N.L.R.B. No. 105 (2001).

221. See Brooks v. NLRB, 348 U.S. 96, 104 (1954) (approving Board's establishment of the certification bar rule). See also Sheridan Manor Nursing Home, Inc. v. NLRB, 225 F.3d 248, $250 \&$ n.1 (2d Cir. 2000) (recent application of the certification bar rule).

222. See H.R. 694, 107th Cong. (2001). 
probably do it little good. In recent years, only about $25 \%$ of newly certified unions have reached a collective bargaining agreement during the certification year, ${ }^{223}$ and the likelihood of success would surely be far lower for a union that lost the support of employees by engaging in underhanded tactics. ${ }^{224}$

Withdrawal of recognition and decertification are not the only ways that employees could punish a union that retracts benefits. Unions, unlike employers, are democratic organizations subject to control by their employee-members. The federal Labor-Management Reporting \& Disclosure Act (LMRDA) requires that national and local union officers be elected by secret ballots cast by union members, ${ }^{225}$ and also requires that increases in union dues and fees be approved by a secret vote. ${ }^{226}$ The LMRDA also requires every union to adopt a constitution and bylaws. ${ }^{227}$ These constitutions, in turn, typically require membership voting and approval of various forms of union business. ${ }^{228}$ Consequently, if local or

223. See Pam Ginsbach, One-Quarter of Newly Certified Unions Reached Contracts in FY 1998, Agency Finds, 79 DAll Y LAB. REP. (BNA) A-2 (April 26, 1999)(discussing that "[f]or the third consecutive year," about one-fourth of newly certified unions obtained a contract in the first year).

224. In Skyline Distributors, the D.C. Circuit opined that employers also had an incentive to avoid retracting benefits because "[their] employees are not foreclosed from restarting a union campaign and insisting on a representation election if the employer later limits or withdraws benefits." 99 F.3d at 408 n.1 (citing Bok, supra note 50, at 114-15). However, there are serious obstacles to "restarting" a successful union campaign. As noted earlier, a union that has lost a representation election must wait at least one year before a second election can be held. See 29 U.S.C. $\$ 159$ (c)(3)(1994). This means that a union will have to carry out an organizing campaign that sustains employee interest in the union for at least one year. For unions, even short organizing campaigns usually demand a tremendous investment in financial and other resources. See, e.g., Goin' South: To Save Itself, Organized Labor Must Capture Dixie, 6 THE BLACK COMMENTATOR (June 27, 2002), at http://www.blackcommentator.com/going_south.html ("Union organizing is expensive, costing thousands of dollars per person."); Barbara Solow, Prescription: Union, THE INDEPENDENT WEEKLY (Sept. 13, 2000), at http://indyweek.com/durham/2000-09-13/

cover.html ("We went to a board meeting recently and we were told you can count on spending $\$ 1,000$ per member to organize a unit .... We just don't have that kind of money."); News for Analysts in Transit (June 1997), at http:www.osaunion.org/campaigns/ jun97 ("Organizing is expensive, stressful, a lot of hard work and not at all guaranteed of success. Most organizing drives fail."). Moreover, unions' rank-and-file members are often resistant to devoting resources to organizing, and such resistance would likely be especially acute when organizing is aimed at a workplace where the union failed before. See Bill Fletcher, Jr. and Richard W. Hurd, Overcoming Obstacles to Transformation, in Rekindling the Movement, supra note 137, at 194-95 (discussing "members" as obstacles to organizing).

225. 29 U.S.C. $\$ 481$ (1994).

226. 29 U.S.C. $\$ 411$ (a)(3) (1994).

227. 29 U.S.C. $\$ 431$ (a) (1994).

228. See generally Roger C. Hartley, The Framework of Democracy in Union Government, 32 CATH. U. L. REv. 13 (1982). 
even national union officers were to retract benefits they had provided employees during an organizing campaign, employees have many opportunities to retaliate against the union by challenging the union's officers in elections and voting against the union's preferences at union meetings.

By contrast, American employers are controlled by owners and shareholders, not by their employees. Employees have no opportunity to "vote out" management officials or to vote against management policies. Employees could complain, but the employer is under no obligation to listen to their complaints. Employees could "vote with their feet" by quitting, but this entails giving up all of the benefits of their jobs and risking protracted unemployment. In sum, unions are less likely than employers to retract benefits provided during representation campaigns, not because unions are morally superior, but because of the practical reality that employees can more easily and effectively penalize unions for such trickery.

There are many other practical considerations that support retaining the prohibition on employer grants of benefits, even if that prohibition is lifted for unions. Employees inevitably know much more about the employer and the benefits provided than they know about the union. Indeed, it has long been recognized that "employees considering unionization seldom possess much direct knowledge concerning the union, its activities, and its potential to bring about better wages and working conditions, while in contrast employees are well aware of the employer's control of wages and working conditions. ${ }^{229}$ This relates to the point made in Part III, that allowing union grants of benefits is necessary to counter the benefits the employer has provided to employees and which the employer is free to remind them of throughout the representation campaign. ${ }^{230}$ In this way, repealing the ban on union benefits would help to equalize the playing field. Removing the prohibition for employers would put employers in a position to wipe out this "equalization" effect.

Inequality between employers and unions in opportunities to benefit employees is another possible justification for preserving the ban on employer benefits during representation campaigns. An employer's relationship with its employees almost always predates that of the union, in many cases by years. The employer, through all this time, has had the chance to grant employees the benefits they may desire. By contrast, the union, virtually by definition, has had no ability to provide benefits until it makes contact with the employees. Such contact often is counted as the beginning of the organizing campaign, or at least close enough to affect

229. 52nd St. Hotel Assocs., 321 N.L.R.B. at 630 (citing Bok, supra note 50, at 49-55).

230. See supra notes $168-70$ and accompanying text. 
it. $^{231}$ Given this enormous head start that employers have over unions in terms of providing benefits, it is not unreasonable to say that employers cannot continue to grant new benefits during the representation campaign, even if unions can.

Another key distinction between unions and employers, which may justify treating their provision of benefits differently, is the point made at the outset of this article. Unions exist to assist employees. That is the reason they are formed, maintained, and operated. Employers are not formed and operated in order to benefit their employees. Instead, they are in business to make widgets or (in our increasingly service-oriented economy) to provide widgeting services. Hence, it could be argued that it is only natural that unions should be in a preferred position over employers in providing benefits to employees, because that is the central function of unions.

The NLRB itself provides some support for this argument. Employees who are already members of a union have a Section 7 right to assist other unorganized employees. ${ }^{232}$ Through their political control of the union, and their financial support of it, it is really the union members who are granting benefits to unorganized employees, and the members are exercising their Section 7 rights in doing so. ${ }^{233}$ Moreover, the unorganized employees have a Section 7 right to receive assistance from a union. Both the Board and courts have recognized that "[t]he giving of aid by a labor union to an employee... is clearly a concerted activity on the part of employees protected by the Act." ${ }^{234}$ By contrast, the NLRA does not establish a positive "right" for employers to give employees assistance or benefits that they desire. Thus, Section 7 of the NLRA provides a strong basis for permitting unions to grant benefits to unorganized employees, while there is no corresponding statutory basis for allowing employers to do the same.

231. See supra note 152 and accompanying text (discussing cases that demonstrate that the prohibition on union grants of benefits is not truly limited to the "critical period" between the filing of an election petition and the holding of the election).

232. See 29 U.S.C. $\& 157$ (stating that "employees shall have the right to . . engage in other concerted activities for the purpose of collective bargaining or other mutual aid or protection").

233. See Eastex, Inc. v. NLRB, 437 U.S. 556, 564 (1978)(establishing that under Section 7 employees have the right, through their union, to assist other employers' employees); see also Brief for Intervenor AFL-CIO at 17, Freund Baking Co. v. NLRB, 165 F.3d 928 (D.C. Cir. 1999) (No. 97-1694)(tying this principle to union grants of benefits in organizing campaigns).

234. See 52nd St. Hotel Assocs., 321 NLRB at 634 (quoting Moss Planing Mill Co. v. NLRB, 206 F.2d 557, 559 (4th Cir. 1953)). The omitted portion of the quote refers to aid in the form of a "prosecution of a claim for back wages", but there is nothing unique about such a lawsuit that makes it more protected by Section 7 than many other forms of assistance that unions regularly provide to their members, and this article contends they should be allowed to extend to unorganized employees. 


\section{CONCLUSION}

The existing rule against unions granting benefits to employees during representation campaigns should be drastically revised. A union should be permitted to provide employees any type of benefits that it has a practice of providing to members or non-member employees whom it represents. For many unions, such benefits would include legal assistance, insurance, educational services, and an array of other benefits that aid employees.

The current rule barring union-provided benefits is premised on the misconception that a union's exclusive role with regard to employees is to represent them in bargaining and in dealings with the employer. As important as that role is, unions have always had much more to offer employees. The current rule prevents many employees from learning about union "extra-workplace" benefits, or from ascertaining the truth about employer charges that union descriptions of such benefits are merely "empty promises." In this way, the Board has imposed on employees a narrow and inaccurate understanding of what unions do and how a union can affect their lives. By allowing unions to perform their core function of assisting employees, by simply letting unions be unions, the Board would greatly enhance the ability of employees to make fully informed decisions about how they can exercise their statutory rights in choosing whether to form or join a union, or to refrain from doing so. 